\title{
THE CONSTITUTIONAL COMMON SCHOOL
}

\author{
MOLLY O'BRIEN $^{1}$ \\ AMANDA WOODRUM ${ }^{2}$
}

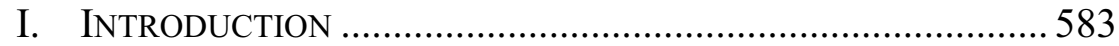

II. "A THOROUGH AND EFFICIENT SYSTEM OF

COMMON SCHOOLS", 587

A. The Early Origins of the "Common School" ...............588

B. New Nationalism and the Seeds of Secularized

Popular Education ………………………………......59

C. Early Schools in Ohio ...............................................593

D. Creating a Climate for Change: Educational Activism and the Common School Movement............... 597

E. A Model of a Complete System of Common

School Instruction for the Whole People ...................... 599

1. The Public Interest in Common Schooling ........... 600

2. The Great Object of Education: A "Thorough Development of all the Intellectual and Moral Powers"

3. A "System" of Education: To "Secure Fidelity and Efficiency". 604

F. The Need for a Constitutional Provision.

G. The Constitutional Convention of 1850-51:

A Common School Mandate

1. A "Thorough and Efficient System of Common Schools" for All Children

2. Eradication of the Greatest Impediment to the Advancement of the Cause, "[T]he rivalry of schools created by different sects".

3. The Ultimate Outcome: A Mandate to the General Assembly to Provide Quality Education

\footnotetext{
${ }^{1}$ Associate Professor of Law, University of Akron School of Law. I would like to thank professors Brant Lee, E. Stewart Moritz, Thomas O'Brien, Elizabeth Reilly, and Tracy Thomas for their comments on earlier drafts of this article and for their help and support with the writing process. I would also like to thank Professor Kevin O'Neill for his excellent work in organizing and editing this symposium volume.

${ }^{2}$ J.D. candidate, University of Akron School of Law, 2004.
} 
III. IMPLEMENTING, CHALlENGING, AND HONING THE

Vision of THE CONSTITUTIONALly MANDATED

COMMON SCHOOLS.

A. The Law of 1853: Reorganization, Supervision, and Maintenance of the Common Schools....

B. Continuing Controversies: Religion, Money, and Control 626

1. Cincinnati v. Minor: The Ohio Constitution Does not Require the Bible Be Used in Schools

2. The Third Constitutional Convention (1874).......628

3. The Constitutional Convention of 1912 Centralizes Authority

IV. The CONSTITUTIONAL "COMMON SCHOOL IDEAL" IN THE CONTEXT OF CONTEMPORARY EDUCATIONAL DEBATES

V. CONCLUSION 642

It has been said, that we ought to trust the management of this interest [schooling] to the General Assembly. But now, for forty-eight years the General Assembly has been entrusted with this matter. Under the old Constitution it is provided that public schools and the cause of education shall be forever encouraged; and, under this constitutional provision, we have trusted the General Assembly for forty-eight years; and we may trust them for forty-eight years longer, without any good result. ... Our system of common schools, instead of improving in legislative hands, has been degenerating; and I think it is time that we establish and carry out an efficient system of common school education or abandon the whole thing entirely to the virtue and intelligence of the people.

-- J. McCormick, $1851^{3}$

[The new education clause] directs the Legislature to make full and ample provision for securing a thorough and efficient system of common school education, free to all the children in the State. The language of this section is expressive of the liberality worthy a great State, and a great people. There is no stopping place here short of a common school education to all children in the State.

-- Samuel Quigley, $1851^{4}$

\footnotetext{
${ }^{3} 2$ Report of the Debates and Proceedings of the Convention for the ReVision of the Constitution of the State of OHio, 1850-51, at 702 (1851)(remarks of Delegate J. McCormick) [hereinafter DEBATES OF 1850-51].

${ }^{4} I d$. at 14 (remarks of Delegate Samuel Quigley).
} 


\section{INTRODUCTION}

No section of the Ohio Constitution has proven more enduringly significant than Article VI, Section 2, which sets forth the legal foundation for public schooling in the state. Adopted following the 1850-51 Convention for the Revision of the Constitution, the section provides:

The general assembly shall make such provisions, by taxation, or otherwise, as, with the income arising from the school trust fund, will secure a thorough and efficient system of common schools, throughout the State; but, no religious or other sect, or sects, shall ever have any exclusive right to, or control of, any part of the school funds of this state. ${ }^{5}$

In a few short phrases, the provision addresses the thorniest issues in the public school arena: the nature of the school system, financial support for schooling, and the role of religious groups in publicly supported education. In the years since this section was made a part of the constitution, virtually every aspect of public schooling has drawn debate and criticism. ${ }^{6}$ It has also been the subject of litigation involving hotly contested questions related to school finance and school choice. ${ }^{7}$ This founding provision, however, has survived unchanged through subsequent constitutional revisions. ${ }^{8}$

Controversy arising from state constitutional education clauses is not limited to Ohio, but instead is representative of a nation-wide debate that challenges the nature of public schooling and calls on the courts to define the state's duty to educate its children. ${ }^{9}$ Every state constitution contains a provision relating to public education. ${ }^{10}$

\footnotetext{
${ }^{5}$ OHIO CONST. art. VI, § 2.

${ }^{6}$ Describing the criticism that public schools receive from all sides, Carl Kaestle wrote, "Public schools, it seems, are too permissive, too strict, too open, too bureaucratic, offensively monolithic and bland in their message, offensively pluralistic and sinful in their message, and have many other failings." CARl F. Kaestle, Pillars of the Republic: Common Schools AND AMERICAN SOCIETY 1780-1860, at 223 (1983).

${ }^{7}$ See, e.g., DeRolph v. State, 97 Ohio St. 3d 434, 780 N.E.2d 529 (2002); Simmons-Harris v. Goff, 86 Ohio St. 3d 1, 711 N.E.2d 203 (1999), rev'd, Zelman v. Simmons-Harris, 536 U.S. 639 (2002).

${ }^{8}$ See infra notes $270-313$ and accompanying text (discussing the constitutional revision conventions held in 1874 and 1912).

${ }^{9}$ There is a vast body of literature discussing school finance and school choice litigation. For an overview of school finance reform litigation, see generally Molly McUsic, The Use of Education Clauses in School Finance Reform Litigation, 28 HARV. J. ON LEGIS. 307, 310 (1991) (analyzing state constitutional claims seeking reform of school financing). "School choice" is an umbrella term that is used to discuss various reform proposals including tuition vouchers, charter schools, and magnet school programs. See generally Peter W. Cookson, Jr., School Choice: The Struggle for the Soul of American Education 14 (1994); Amy S. Wells, Time To Choose 5 (1993).

${ }^{10}$ Allen W. Hubsch, The Emerging Right to Education Under State Constitutional Law, 65 TEMP. L. REV. 1325, 1343-48 (1992) (collecting state constitutional provisions). See also Kern Alexander \& David M. Alexander, American Public School Law 30-32 (4th ed.
} 
Nearly all of these constitutional provisions have recently been the subject of litigation. ${ }^{11}$ Because there is no federal constitutional analogue for these clauses, ${ }^{12}$ the task of interpreting these education clauses falls, virtually unrestricted, to the state courts. ${ }^{13}$

The interpretation of Ohio's constitutional provisions for education is particularly important for several reasons. First, Ohio was a pioneer among the states that sought to establish a system of public schools: Its studies, debates, and resulting constitutional language were examined and used as a model in other state constitutions. ${ }^{14}$ Further, Ohio has been at the forefront of the school choice movement; its pilot program for private school tuition vouchers has been the subject of litigation that has reached both the Ohio and United States supreme courts. ${ }^{15}$ Moreover, recent litigation relating to school choice and to school finance has not exhausted all of the potential constitutional issues. There is good reason to believe

1998) (summarizing the underlying principles that are common to most state constitutional educational provisions and summarizing the differences among several categories of provisions); William E. Thro, The Role of Language of the State Education Clauses in School Finance Litigation, 79 EDUC. L. REP. 19, 19 n.1 (1993) (collecting state constitutional provisions).

${ }^{11}$ The Advocacy Center for Children's Educational Success with Standards (ACCESS) provides on-line updates of school finance litigation implicating state constitutional education clauses in forty-four states, at http://www.accessednetwork.org/statesmain.html (last visited June 28, 2003).

12،"Education, of course, is not among the rights afforded explicit protection under our Federal Constitution. Nor do we find any basis for saying it is implicitly so protected." San Antonio Independent School District v. Rodriguez, 411 U.S. 1, 35 (1973); but see Plyler v. Doe, 457 U.S. 202, 224 (1982) (holding that laws depriving a group of children of an opportunity for a public education merit intermediate scrutiny under the Equal Protection Clause of the U.S. Constitution). In Plyler, the Court acknowledged that "[p]ublic education is not a 'right' granted to individuals by the Constitution," but went on to add, "[b]ut neither is it merely some governmental 'benefit' indistinguishable from other forms of social welfare legislation." Id. at 221.

${ }^{13}$ As the Supreme Court of Ohio has acknowledged, "The system of public education in Ohio is the creature of the constitution and statutory laws of the State." State ex rel. Garnes v. McCann, 21 Ohio St. 198, 204 (1871).

${ }^{14}$ Calvin Stowe's "Report on Elementary Public Instruction in Europe," made to the Governor and Legislature of Ohio in 1837, was reprinted by the legislatures of Massachusetts, Michigan, North Carolina, Pennsylvania, and Virginia. See Calvin E. Stowe, Report on Elementary Public Instruction in Europe, in REPORTS ON EUROPEAN EDUCATION 248, 251 (Edgar W. Knight ed., 1930). Twenty-two state constitutions contain clauses, which, like Ohio's constitution, impose "some minimum standard of quality, usually thorough and/or efficient, that the statewide system of schools must reach." Thro, supra note 10, at 23-24.

${ }^{15}$ Simmons-Harris v. Goff, 86 Ohio St. 3d 1, 711 N.E.2d 203 (1999), rev'd, Zelman v. Simmons-Harris, 536 U.S. 639 (2002). 
that the Ohio Supreme Court will be called on to interpret the education clause again. ${ }^{16}$

State courts have taken various approaches to interpreting the language of their constitutional education clauses: They have turned to the plain meaning of the constitutional text, to historical evidence regarding the intent of the framers, to longstanding practice, or to judicial interpretations of similar language by other courts. ${ }^{17}$ In Ohio, the task of interpreting the constitution is to "accomplish the manifest purpose" of the provision. ${ }^{18}$ The Ohio Supreme Court has said:

We are not to use any millimeter measure of interpretation nor employ that strict construction peculiar to criminal law and procedure, but we are to employ that broad-gauged liberal construction that the general terms of constitutional provisions necessarily require in order to make them effective and carry out the real intention of the people in making the Constitution, through their representatives, and by adopting the Constitution by their own votes. The polestar in the construction of Constitutions, as well as other written instruments, is the intention of the makers and adopters. ${ }^{19}$

The process of uncovering this "manifest purpose" is not confined by the particular traditions or practices in place at the time of adoption. Constitutional framers may use constitutions to counter or transcend - rather than embodyexisting community realities. ${ }^{20}$ The interpretation is not limited to the specific understandings of the particular people who drafted and adopted the provision. Rather, the pursuit of the "real intention of the people" is best understood as a search for the values that the framers have enshrined in the constitution. ${ }^{21}$ This search for constitutional values, then, is a search for principles or an "ethos" that animates and illuminates the aspirations of the constitutional framers. ${ }^{22}$

In this paper we turn to historical evidence as a beginning point for understanding the constitutional vision and values of the "thorough and efficient system of common schools" mandated by Article VI, Section 2 of the Ohio Constitution. In Part II, we

\footnotetext{
${ }^{16}$ See, e.g., Catherine Candisky, School Funding Case; Coalition Seeks High Court's Help, Columbus Dispatch, June 25, 2003, at B8 (reporting on continuing efforts to enforce Ohio constitutional education clause provisions).

${ }^{17}$ John Dayton, An Anatomy of School Funding Litigation, 77 EDUC. L. REP. 627, 641-43 (1991) (describing methods of constitutional interpretation used by various state courts). See also Robert Schapiro, Identity and Interpretation in State Constitutional Law, 84 VA. L. REV. 389,445 (1998) (pointing out that courts often resorted to more general arguments about the constitutional values at stake).

${ }^{18}$ State ex rel. Swetland v. Kinney, 69 Ohio St. 2d 567, 570, 433 N.E.2d 217, 220 (1982). See also Castleberry v. Evatt, 147 Ohio St. 30, 67 N.E.2d 861 (1946) (syllabus $₫ 1$ 1).

${ }^{19}$ Hockett v. State Liquor Licensing Board, 91 Ohio St. 176, 110 N.E. 485 (1915) (upholding a 1912 "Home Rule" amendment to the Ohio Constitution).

${ }^{20}$ Schapiro, supra note 17 , at 394.

${ }^{21}$ Id. at 393.

${ }^{22}$ Id. at 451-56.
} 
consider the early development of public schooling in America and the complex relationship between public education and religion. The common school, as envisioned by the Ohio crusaders for its establishment, would bring diverse peoples together to create a common sense of citizenship. It would provide for citizen equality, and social and economic mobility; and it would safeguard liberty by developing a polity capable of self-government. ${ }^{23}$ The common school vision competed, however, with the existing reality of schools that were tuition-based, locally governed, diverse, and sectarian. ${ }^{24}$

Prior to 1851, the conflict over competing visions of schooling-one embraced primarily by Protestant school crusaders, the other embraced by the Catholic Church - had escalated into violent conflict in New York City and Boston. ${ }^{25}$ In Ohio, conflict relating to the nature of public education, and, more specifically, the use of public money for sectarian schools had not become violent, but had been vigorously debated since $1789 .{ }^{26}$ The inclusion of the educational provisions in the Constitution of 1851 represented a victory for the advocates of a non-sectarian, stateoperated system of schools that would encourage civic participation and avoid religious indoctrination. ${ }^{27}$

In Part III, we address efforts made to revise the state's educational provisions through constitutional amendments in 1874 and again in 1912. In considering and rejecting various amendments to Article VI, Section 2, the delegates to these conventions reinforced and redefined the non-sectarian ethos of public education. They also added new provisions to centralize authority for the efficient administration of education and to ensure state oversight over a single system of schools. $^{28}$

Finally, in Part IV, we attempt to place the constitutional "common school ideal" in the context of contemporary educational debates. Advocates for school choice have argued that both religious and private schools attend to the values of equality and civic participation while allowing for diversity in values, religious views, and educational approaches. One well known proponent of school choice has claimed, "Catholic schools more nearly approximate the 'common school' ideal of American

\footnotetext{
${ }^{23}$ See infra notes 101-50 and accompanying text. New York CiTY, 1805-1973 (1974). EDUCATION IN THE OLD NORTHWEST].

${ }^{26}$ JONATHAN F. BUCHTER, ET AL., OHIO SCHOOL LAW 60 (2000).

${ }^{27}$ See infra notes 164-249 and accompanying text.

${ }^{28}$ See infra notes 270-313 and accompanying text.
}

${ }^{24}$ Edward Anson Miller, The History of Educational Legislation in OHio From 1803 to 1850, at 17-53 (1920). See generally Diane Ravitch, The Great School Wars:

${ }^{25}$ Ravitch, supra note 24; see Carl E. Kaestle, The Development of Common School Systems in the States of the Old Northwest, in "...SCHOOLS AND THE MEANS OF EduCATION SHAll Forever Be EnCOURAGED”: A History OF EduCATION IN THE Old NorTHWEST, 17871880, at 31, 32 (Paul H. Mattingly \& Edward W. Stevens, Jr. eds., 1987) [hereinafter 
education than do public schools. ${ }^{29}$ The authors of this paper, however, suggest that the ethos or constitutional vision of the common school is at odds with expanding programs that support private and religious school choice. ${ }^{30}$

\section{II. "A ThOROUGH AND EFFICIENT System OF COMMON SCHOOLS"}

During the 1851 constitutional convention debates on the education clause, one of the delegates, Mr. Archibold, rose to argue that the word "common" should be stricken from the clause and the word "useful" substituted. ${ }^{31}$ Mr. Archibold argued, "At the present time there is no difficulty in ascertaining what [common school] means, but a time might come when retaining its present limit of definition, it might stand in the way of further and necessary improvements in the school system." ${ }^{32}$ His colleagues scoffed at his concern. "Common schools in the future will be common schools," responded Mr. Humphreville, "- that is to say they will not be uncommon schools." 33

The meaning of the term "common school" was so clear to the framers of the 1851 Constitution that its definition hardly merited serious discussion. That meaning had been etched in the public mind through the efforts of educational activists who campaigned vigorously through the 1830 s and 40 s for the establishment of free,

${ }^{29}$ Richard W. Garnett, The Right Questions About School Choice: Education, Religious Freedom, and the Common Good, 23 CARDOZO L. REV. 1281, 1301 (2002) (quoting JAMES Coleman et Al., High School Achievement 185 (1982)).

${ }^{30}$ In so doing, we join numerous other scholars who find continuing vitality in the ideal of an integrative system of public education. See, e.g., GARY Orfield \& SUSAN EATON, Dismantling Desegregation: The Quiet Reversal of Brown v. BoArd of Education (1996)(discussing the dismantling of desegregation and suggesting strategies for the implementation of the integrative ideal); DAVID TYACK \& LARRY CUBAN, TINKERING TOWARD Utopia: A CENTURY OF PUBlic SCHOOL REFORM (1995)(the democratic purposes that guide public education must figure into educational reform efforts); JONATHAN ZIMMERMAN, WHOSE America? Culture Wars in the Public School (2002)(public schools should allow for diversity of views within one school); Kevin Brown, Equal Protection Challenges to the Use of Racial Classifications to Promote Integrated Public Elementary and Secondary Student Enrollments, 34 AKRON L. REV. 37 (2000) (explaining the value of integration in the schools); Richard D. Kahlenberg, Socioeconomic School Integration Through Public School Choice: A Progressive Alternative to Vouchers, 45 HowARD L.J. 247 (2002) (choice should take place within the system of public schools to further the goals of equal opportunity and education for democracy). See generally Symposium: The ReSEgregation OF SOUTHERn Schools? A Crucial Moment in the History (and Future) of Public Schooling in America, 81 N.C. L. REV. (2003).

${ }^{31} 2$ DEBATES OF 1850-51, supra note 3, at 698.

${ }^{32} I d$. at 698 (Mr. Archibold was concerned that "common" was too limiting a term on the discretion of the General Assembly, and might stand in the way of further and necessary improvements in the school system. He hoped to see the common schools advance, not only to meet such demands as were then made upon them, but to meet higher and greater needs. He wanted to see a system of schools "as perfect as could be devised," that was capable of improving to keep pace "with the most rapid progress of the most rapid element of our social or political constitution.").

${ }^{33} I d$. at 699 . 
universal schooling. These activists used the term "common school"-which had formerly been used to refer to any basic or elementary education-to refer specifically to a non-sectarian, publicly funded school where children of all classes and backgrounds would be educated together. These education activists, who shared a progressive vision of schooling and society, gave the term "common school" its constitutional meaning. The following section attempts to clear away the dust of years to more fully understand the meaning and content of a constitutionally required "thorough and efficient system of common schools." ${ }^{.34}$

\section{A. The Early Origins of the "Common School"}

A search for the meaning of the term "common school" begins in Europe in the late Middle Ages, when the feudal system began to decline, cities grew, and trade increased. ${ }^{35}$ Throughout the Middle Ages, the Catholic Church held a virtual monopoly on formal education. This monopoly began to deteriorate as the new class of merchants and tradesmen found it necessary to learn to read, write, and cipher to keep up with their burgeoning businesses. ${ }^{36}$ Reading and writing, which had formerly been taught almost exclusively in Greek and Latin to nobles and clergy, now began to be taught in the vernacular to common folk. ${ }^{37}$ As townspeople tried to establish vernacular schools, the schools often faced ecclesiastical veto, bringing church and town officials into conflict. ${ }^{38}$ Nevertheless, by 1500 numerous cities in Europe had established vernacular schools that were supported, in part, through taxation. ${ }^{39}$

\footnotetext{
${ }^{34}$ There are a number of excellent works that chronicle the development of the common school and its ideological foundations. See, e.g., Frederick M. Binder, The Age of the Common School, 1830-1860 (1974); Lawrence A. Cremin, American Education: The National Experience 1783-1876 (1980); Charles Leslie Glenn, The Myth of the Common School (1988); Kaestle, supra note 6; EdWARd H. Reisner, The Evolution of the Common School (1930); David Tyack \& Elisabeth Hansot, Managers of Virtue: Public SCHOOL LEAdERSHIP IN AMERICA, 1820-1980 (1982).

${ }^{35}$ REISNER, supra note 34, at 2 (claiming that the common school is a "direct descendant" of European vernacular schools of the late Middle Ages).

${ }^{36} I d$. at 6-7.

${ }^{37} I d$. at 11-17. The Roman Catholic Church developed a system of religious education in which the trivium (grammar, rhetoric, and dialectics) and quadrivium (arithmetic, geometry, music, and astronomy) were taught along with religious instruction using primarily Greek and Roman texts. John Witte, Jr., The Civic Seminary: Sources of Modern Public Education in the Lutheran Reformation of Germany, 1996 J. LAW \& RELIG. 173, 180-182. Vernacular schools were not part of the Church's system of Latin schools and were permitted to give instruction only in the vernacular language. Teaching Latin and religious doctrine remained in the domain of the Church. REISNER, supra note 34, at 13-17.

${ }^{38}$ REISNER, supra note 34 , at 13 .

${ }^{39}$ Witte, supra note 37 , at 182 . Professor Reisner includes Paris, London, and cities in Italy among those that established city school systems. REISNER, supra note 34, at 16.
} 
In the years following the Protestant Reformation and the invention of the printing press, the vernacular school model was expanded and transformed. ${ }^{40}$ The printing press made reading material more widely available, providing a powerful incentive to learn to read and increasing the demand for education. The Protestant Reformation also fueled the new demand for schooling. Protestantism supported the expansion of schooling in two important respects: First, Protestant theology advanced the belief that all persons should be educated in order to read the Bible and use it as a tool to develop a personal relationship with and understanding of God; and second, it placed the responsibility on the political authority to provide education. ${ }^{41}$ Civil authorities responded to the new theology by establishing schools and passing compulsory attendance laws. ${ }^{42}$ These schools, provided by secular authorities in places where state-established religion was the norm, were religious in both content and mission. ${ }^{43}$

Early immigrants to America set up schools in keeping with their European traditions. Given the "threat of barbarism implicit in the wilderness" and the need for political and economic self-sufficiency in the unsettled lands, colonial governments moved quickly to legislate on the subject of education. ${ }^{44}$ In 1647, Massachusetts lawmakers, noting that it was "the chief project of ye old deluder, Satan, to keep men from knowledge of the Scriptures," passed a law requiring every township of fifty households or more to hire a teacher and every town with more than 100 households to establish a grammar school. ${ }^{45}$ The stated purpose of the law was to ensure that children could read the Bible, in keeping with the ideals of the

\footnotetext{
${ }^{40}$ Some scholars contest the thesis that the Protestant Reformation was responsible for the expansion of the common vernacular schools and assert that new social forces unrelated to the Reformation led to the eventual improvement in education that took place in the Eighteenth Century. REISNER, supra note 34, at 29.

${ }^{41}$ Harold Berman, The Interaction of Spiritual and Secular Law: An Historical Overview, with Special Reference to Sixteenth-Century Lutheran Germany, in STUDIES IN COMPARATIVE Legal History, LeX et Romanitas: EsSAys FOR Alan WATSON 163 (Michael Hoeflich ed., 2000). These educational ideas were grounded in Martin Luther's doctrine of two kingdoms, one heavenly and one earthly. In this theology, the heavenly kingdom requires the individual to be educated to allow for spiritual flourishing and responsible decision-making; the earthly kingdom requires education to deal effectively with earthly affairs. Witte, supra note 37 , at 187-205. See also REISNER, supra note 34, at 24-41. Other branches of Protestantism similarly posited the importance of each individual's experience of spiritual life. European Calvinists, Presbyterians, and English Puritans all supported and developed community schools. Id. at 29-41.

${ }^{42}$ In spite of compulsory attendance laws, many children undoubtedly did not attend school because of high fees or because their parents could not spare them from work. Berman, supra note 41, at 163 n.46 (citing Gerald Strauss, Luther's House OF LEARNing 23, 26 (1978)).

${ }^{43}$ Witte, supra note 37, at 219.

${ }^{44}$ Lawrence A. Cremin, American Education: The Colonial Experience 1607-1783, at $124-27(1970)$.

${ }^{45}$ We have modernized the spelling in the quoted sections. The full text of the act, with its original spelling, is quoted in ALEXANDER \& ALEXANDER, supra note 10, at 27.
} 
Protestant Reformation. ${ }^{46}$ Connecticut, Pennsylvania, New York, and Virginia all passed laws prior to 1700 requiring children to be taught reading, religious subjects, and useful trades. ${ }^{47}$

Although early colonial legislation seemed to embrace the European tradition of schools organized by secular authorities with distinct religious affiliation and purpose, a new set of social circumstances altered the development of educational institutions here. Eighteenth Century America was characterized by sparsely populated rural and frontier areas and minimal government presence. Schooling in the colonies was accomplished primarily by parental initiative and informal, locally controlled institutions including a variety of church-affiliated and private schools. ${ }^{48}$ Moreover, evangelical spiritual movements of the Eighteenth Century, known as the "Great Awakening," led to a progressive "splintering" of the Protestant faith. This splintering complicated the relationship between church-affiliated schools and officially established religion. ${ }^{49}$

As congregations were torn apart, disagreement on spiritual matters created political conflict among tax-supported churches and their affiliated schools. ${ }^{50}$ In colonies with officially established religion, sectarianism became not only a battle for souls, but also a competition for tax money and the right to educate the next generation. ${ }^{51}$ As colonial society became ever more heterogeneous and as freedom of conscience continued to be an important issue and principle, anti-sectarian or pansectarian approaches to education began to take root. Zealous sectarianism, paradoxically, created a need to search for common ground and thus accelerated the development of a "general Christian education." 52

\section{B. New Nationalism and the Seeds of Secularized Popular Education}

On March 1, 1781, the United States of America came into existence when the last of the thirteen states joined the Confederation of States. ${ }^{53}$ The dawn of a new

\footnotetext{
${ }^{46}$ Harl R. Douglass \& Calvin Grieder, American Public Education: An INTRODUCTION 14 (1948).

${ }^{47}$ CREMIN, supra note 44 , at 124-25, 181-83.

${ }^{48}$ KAESTLE, supra note 6, at 3; GLENN, supra note 34, at 16.

${ }^{49}$ L. Glenn SMith \& JoAn K. Smith, Lives in Education: A NarRative of People and IDEAS 240-41 (2d ed. 1994).

${ }^{50}$ CREMIN, supra note 44 , at 316-18.

${ }^{51}$ Id. See also Raymond B. Culver, Horace MANn AND Religion IN the Massachusetts Public Schools 13-15 (1929) (describing the relationship between the state and tax-supported churches in Massachusetts between 1631 and 1780).

${ }^{52}$ CREMIN, supra note 44, at 331 (“As Sidney Mead once put it, zealous sectarianism tended to be swallowed up in a larger whole; and in the academies and colleges, even more, perhaps, than in the churches, Americans found common ground, common opportunity, and common cause.").

${ }^{53}$ James J. Burns, Educational History of Ohio: A History of its Progress Since the Formation of the State Together With the Portraits and Biographies of Past AND Present State Officials 7 (1905).
} 
nation brought with it new thinking about the purpose and potential of schools. While schools had previously been valued for both economic and religious reasons, they now began to be envisioned as a cornerstone of republican self-government. ${ }^{54}$ The diffusion of knowledge was seen as instrumental in the struggle against tyranny and integral to the success of the new experiment in republican self-government. Thomas Jefferson, in the preamble to a bill that proposed a system of publicly supported schools in Virginia, wrote:

[I]t is believed that the most effectual means of preventing [tyranny] would be, to illuminate, as far as practicable, the minds of the people at large, and more especially to give them knowledge of those facts which history exhibiteth, that, possessed thereby of the experience of other ages and countries, they may be enabled to know ambition under all its shapes, and prompt to exert their natural powers to defeat its purposes. ${ }^{55}$

American Revolutionary thinkers were concerned not only with the tyranny of monarchy, but also with the tyranny and ambition of organized religion. The elite group of influential Americans, after a long struggle to defeat monarchy, was determined to avoid both the feudal and the canon systems. ${ }^{56}$ Education and public debate, it was believed, would expose both religious and worldly schemes designed to enslave the people. ${ }^{57}$ In order to be liberating, rather than enslaving, it was thought that education should not be church-controlled. ${ }^{58}$ Thus, the Revolutionary generation, influenced by Enlightenment philosophy, brought a new thread of anticlerical thinking to American educational philosophy. ${ }^{59}$ True wisdom and virtue could not be taught by "monkish scholars" who taught orthodoxy and subservience, but by reading, reason, and conversation with all sorts of men. ${ }^{60}$

For the intellectual elite of the Revolutionary generation, the Enlightenment values of individualism, rationalism, and nationalism supported a vision of popular education for secular rather than religious purposes. This is not to say that religion played no part in this new national view of education. John Adams, for example, viewed the post-Reformation expansion of European education and the subsequent

\footnotetext{
${ }^{54}$ Even before the American Revolution, innovative educational theories drawing from European thinkers like Locke, Rousseau, Adam Smith, and others, had found a "testing ground" in Philadelphia. CREMIN, supra note 44, at 378.

${ }^{55}$ Cremin, supra note 44, at 440 (quoting Jefferson's "Preamble to a Bill for the More General Diffusion of Knowledge").

${ }^{56} I d$. at 417 (quoting John Adams).

${ }^{57} I d$. at $415-18,427-28$.

${ }^{58} I d$.

${ }^{59}$ See id. at 424-36. In describing this new anti-clerical thinking, Lawrence Cremin notes the belief that "good learning involves a constant reference to liberty, law and patriotism, to those great principles of reason and justice that must be at the heart of all free government. The ancients were well aware of this and placed their academies in the hands of public-spirited philosophers [rather than priests]." Id. at 425.

${ }^{60} I d$. at 427-28. Thomas Jefferson, John Locke, and others believed that essential education takes place outside the school, in the arena of public affairs. Id. at 429, 442.
} 
transition from European feudal serfdom to American self-governing citizenship as part of God's plan. ${ }^{61}$ In keeping with John Adams's view, many of the intellectual elite approached education with an "almost messianic" sense of mission. For them, "America [was] the new Israel living under a special covenant with God and dedicated to carrying the benefits of the arts and sciences to their highest form." Professor Witte explains:

Reason was no longer the handmaiden of revelation, rational disputation no longer subordinate to catechetical declaration. The rational process, conducted privately by each individual and collectively in the open marketplace of ideas, was considered a sufficient source of private morality and public law. The nation-state was no longer identified with the national church, nor the magistrate treated as the vice-regent of God or the father of the community. The nation-state was to be glorified in its own right, its constitutions and democratic processes to be celebrated as the new sacred texts and rites of the American people. ${ }^{63}$

With the exaltation of reason, rationality, and democracy came a faith in education to form and reform the society. Men like Thomas Jefferson, John Adams, Benjamin Rush, and Benjamin Franklin spoke and wrote about the importance of education in maintaining order, creating a new national identity, and developing the virtues necessary for republican citizenship. ${ }^{64}$ Their efforts to establish free statesupported school systems, however, were largely unsuccessful. ${ }^{65}$ Schooling in the new states continued much as it had during the colonial period: intermittent, unevenly distributed, and supported by parental initiative and tuition money rather than by state organization. Nevertheless, the Revolutionary generation planted the seeds of the future public school system. Particularly, the program of land grants that they initiated in 1785 "prepar[ed] the United States for a policy of universal, free, public education." ${ }^{.66}$

\footnotetext{
${ }^{61} I d$. at 416.

${ }^{62}$ Id. at 561 .

${ }^{63}$ Witte, supra note 37 , at 221.

${ }^{64}$ Each of these men had distinct views about the ideal nature and purpose of a publicly supported education. For a summary of the contrasting educational values and interests of some of the nation's founders, see Molly O'Brien, Free at Last: Charter Schools and the Deregulated Curriculum, 34 AKRON L. REV. 137, 141-43 (2000) (citing additional relevant sources).

${ }^{65} \mathrm{KAESTLE}$, supra note 6 , at 61 .

${ }^{66}$ REISNER, supra note 34 , at 288; BURNS, supra note 53, at 11-16. Prior to this date, the Continental Congress passed resolutions recommending that the outlying territories held by a few states be ceded to the general government for the common benefit of the United States. The Congress pledged by resolution that such lands ceded to Congress would be settled, formed into distinct states, and made members of the federal union with the same rights of sovereignty as the other states. These resolutions were affirmed in the Northwest Ordinance of 1787, which also served as a compact between the general government and the states unborn. The ordinance embodied a form of government that collectively and individually bound settlers in the Northwest Territory.
} 
The Northwest Ordinance of 1785 mandated that a section of land in each town in the Northwest Territory be set aside for the support of schools. ${ }^{67}$ The land was not necessarily to be the site of schools, but was to be rented out and the profit used to support schools. ${ }^{68}$ The Northwest Ordinance of 1787 followed, expressing a commitment to universal education. It stated: "Religion, morality and knowledge, being necessary to good government and the happiness of mankind, schools and the means of education shall be forever encouraged." ${ }^{\circ 9}$

\section{Early Schools in Ohio}

The commitment to education was reiterated in Ohio's founding documents. In 1800 , the Northwest Territory was divided into two parts, the eastern portion being what is now Ohio. ${ }^{70}$ During the negotiations for statehood, the Ohio delegates agreed not to tax lands sold by the federal government for five years. In return, the Ohio delegation proposed that the title to all the school lands be vested in the state and not in the people of the townships. ${ }^{71}$ The proposition was put into a bill, passed by Congress, and signed by the President, creating a state fund that would be spent for educational purposes. ${ }^{72}$ Thus, the state and the state fund for education came into being simultaneously.

The first constitution of Ohio also recognized the importance of education. A constitution for Ohio was adopted in 1802, incorporating a provision that echoed the language of the Northwest Ordinances and added a provision to ensure religious tolerance. $^{73}$ It stated:

[R]eligion, morality, and knowledge, being essentially necessary to good government and the happiness of mankind, schools and the means of instruction shall forever be encouraged by legislative provision, not inconsistent with the rights of conscience. ${ }^{74}$

67"An Ordinance for Ascertaining the Mode of Disposing Lands in the Western Territory," May 20, 1875, as quoted in David Tyack, Forming Schools, Forming States: Education in a Nation of Republics, in EDUCATION IN THE OLD NORTHWEST, supra note 25, at 20.

${ }^{68}$ Kaestle, supra note 25 , at 32.

${ }^{69} I d$. The Ordinance of 1785 was meant to attract settlers to the territory by providing means to support education.

${ }^{70}$ BuRNS, supra note 53, at 17.

${ }^{71}$ Id.

${ }^{72}$ Tyack, supra note 67 , at 23 . The state then delegated responsibility for control of the fund back to the local communities. Id.

${ }^{73}$ Soon after the adoption of the Constitution, Ohio became the first state from the Northwest Territory to be admitted to the Union. MiLler, supra note 24, at v; B.A. HinsDale, The Old Northwest: The Beginnings of our Colonial System 307-15 (Boston, Silver, Burdett \& Co. 1899)(1888).

${ }^{74}$ Ohio Const. of 1802, art. VIII, §3. See Ohio, in Education In the STATEs: Historical Development And Outlook 948, 951 (Jim B. Pearson \& Edgar Fuller eds., 1969) [hereinafter EDUCATION IN THE STATES]. 
Access to the schools supported by the state fund was guaranteed in the Bill of Rights of the Ohio Constitution of 1802. Seeking to end existing discrimination against poor children by state-supported schools, its drafters inserted a provision requiring that "no law shall be passed to prevent the poor in the several counties and townships within this state from an equal participation in the schools." ${ }^{.75}$ Any school receiving support from the school fund was required to "be open for the reception of scholars ... without any distinction or preference whatever." ${ }^{.76}$

In spite of the plans made for a state school fund and the grand vision of a system open to all scholars, federal support for schools failed to generate sufficient funds to support the creation of a free school system. ${ }^{77}$ Because land could be purchased cheaply, it was difficult to find renters for the state property. Further, because the attention of settlers was devoted to the pressing daily needs of surviving and civilizing a vast wilderness, there was little public oversight of the school fund; and the fund became vulnerable to fraud and diversion. ${ }^{78}$ Ultimately, the creation of a state-regulated, free school system could not depend on land grants from the federal government because they yielded only an unstable and inadequate fund. The establishment and success of such a system would require a transition from the landuse scheme to a system supported by general taxation. ${ }^{79}$

During the early Nineteenth Century in Ohio, the term "common school" was used to denote any school delivering basic education. The education delivered by these schools was uneven, intermittent, and supported primarily by parents paying tuition. In 1837, Samuel Lewis, Ohio's first State Superintendent of Common Schools, traveled on horseback over bad roads and sparsely settled country to assess the condition of the state's schools and to arouse interest in the need for a better school system. ${ }^{80}$ He reported to the state legislature in 1838 that very few places in Ohio had free schools. Many towns used their public school money for "strictly private" schools that excluded poor children. ${ }^{81}$ Other towns had schools that were

\footnotetext{
${ }^{75}$ OHIO CONST. of 1802 , art. VIII, $\S 25$ ("That no law shall be passed to prevent the poor in the several counties and townships within this state from an equal participation in the schools, academies, colleges and universities within this state, which are endowed, in whole or in part, from the revenue arising from donations made by the United States, for the support of schools and colleges; and the doors of the said schools, academies and universities, shall be open for the reception of scholars, students and teachers, of every grade, without any distinction or preference whatever, contrary to the intent for which said donations were made."). See SUSAN C. Hastings, eT AL., OHiO SCHOOL LAW $§ 1.4$ (2002).

${ }^{76}$ OнIо CONST. of 1802 , art. VIII, § 25. Notably, this constitutional language was held not to preclude the establishment of separate school districts for black and white students in Cincinnati. Ohio ex rel. Directors of Eastern and Western School Districts of Cincinnati v. City of Cincinnati, 19 Ohio 178 (1850).

${ }^{77}$ Kaestle, supra note 25 , at 32 .

${ }^{78} I d$.

${ }^{79} I d$. at 33 .

${ }^{80}$ See EdUCATION IN THE STATES, supra note 74, at 953; BuRns, supra note 53, at 168-69.

${ }^{81}$ Miller, supra note 24, at 30 (citing the first report of Samuel Lewis as State Superintendent of Common Schools: "In some towns all the teachers receive a portion of the
} 
mobbed because they were only open three months of the year. In these towns, people with enough money to pay tuition withdrew their children from the publicly supported school, which worked to stigmatize the publicly funded school as a "poor school." ${ }^{\prime 2}$ Education across the state was a patchwork of whatever the local people were able and willing to support. Early schools met in warehouses, courthouses, and hotel dining rooms. ${ }^{83}$ Groups of parents often organized to create schools; churches ran charity schools; school districts operated with only a "pittance" of state support and no real state regulation. ${ }^{84}$

Samuel Lewis reported that "the people have not heretofore followed any particular system. The directors of each district have done that which was right in their own eyes, and generally adopted, as far as they could, the particular system of the state from which they came." ${ }^{\prime 5}$ For example, in areas populated by settlers from New England, where publicly supported education was valued highly, settlers had established locally supported and controlled public schools. ${ }^{86}$ Like the schools in the Northeast, where most of these settlers immigrated from, these schools were supported by a mix of tax funds, tuition, in-kind payments, and philanthropic grants. ${ }^{87}$ In much of rural and southeastern Ohio, on the other hand, schooling was

public money at the rate of so much per scholar, which they deduct from the subscription price. In these cases the schools are all strictly private, and no provision whatever is made for the poor. The officers in one place where this practice prevails, said that if the schools were free, they would be so crowded as to be useless, unless they had more funds, but by the mode they adopted, every man who sent to school got a part of the public money;' if he was not able to pay the balance he was punished by losing the whole; which is certainly a bad feature in the practice, and a gross violation of the law.").

${ }^{82} I d$. at 29 (citing the first report of Samuel Lewis as State Superintendent of Common Schools: "In one town a free school is taught three months in the year, by one teacher, in a district where more than one hundred children desire to attend; they rush in and crowd the school so as to destroy all hope of usefulness; the wealthy and those in comfortable circumstances, seeing this, withdraw their children or never send them; the school thus receives the name of a school for the poor, and its usefulness is destroyed." Samuel Lewis also complained of a tuition-based system of schooling, stating "[a]nother class proceeds [on a subscription-based system], with the exception that the teacher is bound to take the very poor free, if they prove their total inability to pay. This is but little, if any better than the last, since the poor woman must humble herself, and in effect take the benefit of the poor law, before she can get her children into school.").

${ }^{83}$ Kaestle, supra note 25 , at 38 .

${ }^{84} I d$. at 36-39 (the state aid that existed was added to local funds and fees paid by parents for support of this "patch-quilt of quasi-public and semi-private schools").

${ }^{85}$ MiLler, supra note 24, at 7 (noting that four of the most influential men were born in Massachusetts, including Samuel Lewis, the first State Superintendent of Common Schools). See Education in the States, supra note 74, at 950; General Assembly of Ohio, A History of Education in OHio: A Centennial Volume 86-89 (1876) [hereinafter EDUCATION IN OHIO].

${ }^{86}$ See EdUCATION IN THE STATES, supra note 74, at 950.

${ }^{87}$ Kaestle, supra note 25 , at 35. 
considered to be a parental responsibility and most schools were privately supported. ${ }^{88}$

The qualifications of teachers and the content of the curriculum were similarly uneven. Although in some areas, the status of the teacher was on equivalent footing with that of the physician, ${ }^{89}$ in other areas, the only people who became teachers were those who were unfit to do manual labor. ${ }^{90}$ Because wages were low, teachers often combined jobs. ${ }^{91}$ Some were farm workers, tavern-keepers, or craftsmen on the side. Others taught for only a short time before entering another career or marriage. ${ }^{92}$ With no standard curriculum in place, the educational expectations of many parents were met when children could read the Bible and write somewhat legibly. ${ }^{93}$ Children typically used rote memorization, repetition, and recitation to learn basic subjects. ${ }^{94}$ Only a few went on to more advanced learning in academies; and these institutions were funded entirely through private sources. ${ }^{95}$

During this period, "not all children went to school and not all went to the same school." 96 Although most white children attended some school for at least a few years, terms were short and attendance was irregular. ${ }^{97}$ Black and Native American children generally attended separate schools or none at all; and various ethnic and religious groups established separate schools and competed vociferously for public funds. ${ }^{98}$ Some communities in Ohio provided public funds to religious and foreignlanguage schools under the authority of an 1842 law. ${ }^{99}$ The patchwork of programs

${ }^{88}$ See EDUCATION IN THE STATES, supra note 74, at 950.

${ }^{89}$ See BuRns, supra note 53, at 21.

${ }^{90} \mathrm{Id}$.

${ }^{91}$ KAESTLE, supra note 6, at 20.

${ }^{92}$ Id. See also Kathryn Kish Sklar, Female Teachers: "Firm Pillars" of the West, in EDUCATION IN THE OLD NORTHWEST, supra note 25, at 57-67 (describing the feminization of teaching and the impact of women teachers on schooling in the old Northwest).

${ }^{93}$ See BURNS, supra note 53, at 21.

${ }^{94}$ EdUCATION IN OHIO, supra note 85, at 89-90, 103-04; KAESTLE, supra note 6, at 18-19. For further description of the curriculum and pedagogical methods commonly used by early Nineteenth Century teachers, see id. at 17-23; RAVITCH, supra note 24, at 11-16 (describing the Lancasterian monitorial system).

${ }^{95}$ Kaestle, supra note 25 , at 38 .

${ }^{96} I d$. at 40 .

${ }^{97} I d$.

${ }^{98}$ Id. at 40-41; see KAESTLE, supra note 6, at 14; BERNARD BAILYN, EdUCATION IN THE Forming OF AMERICAN SOCIETY 44-45 (1960); CREMIN, supra note 34, at 104-05; State v. Cincinnati, 19 Ohio 178 (1849)(upholding a Cincinnati ordinance creating separate school districts for black and white children).

${ }^{99}$ Kaestle, supra note 25, at 37. See 1842 Ohio Laws 40, 49-53. 
sometimes heightened ethnic and religious tensions and accomplished only a rudimentary education for most students. ${ }^{100}$

\section{Creating a Climate for Change: Educational Activism and the Common School Movement}

When Samuel Lewis first reported on the state's schools in 1838, he noted that Cincinnati was the only city in the state providing schooling that was free for all and supported by local taxation. ${ }^{101}$ By 1855 , however, most cities, towns, and villages in Ohio had established free school systems, erected school buildings, established graded schools with a 36-week term, and increased teacher salaries. ${ }^{102}$ This remarkable spurt of institution-building was supported by improved transportation and communication, by the increasing complexity of economic life in cities and towns, by population growth, and by the perceived need for greater unity and social discipline. ${ }^{103}$ It was propelled, however, by the common school movement, an extraordinary campaign for the establishment of universal, free, state-supported education that swept the state and overcame all opposition. ${ }^{104}$

The common school movement engaged the energies and efforts of prominent, well-educated men and women, primarily from New England, New York, Pennsylvania, and the Midwest, who "corresponded with each other, consulted each other, copied each others' writings, and copied each others' legislation." ${ }^{\prime 105}$ Some of the activists who "spearheaded the public school movement, articulating its ideals, publicizing its goals, and instructing one another in its political techniques" were teachers. Others were attorneys, clergymen, and editors. All shared a belief in the power and importance of common schooling. These proponents of state action labeled themselves the "friends of education," and advocated state legislation to bring order to the chaos of individualized approaches. ${ }^{106}$

\footnotetext{
${ }^{100}$ Kaestle, supra note 25, at 37 (describing dispute in Columbiana County, Ohio between German and non-German population over use of public money to fund German-language schools and unavailability of a German curriculum in the public school). For a discussion of the tension, debate, and competition among religious denominations regarding higher education in early Nineteenth Century Ohio, see Peter Dobkin Hall, The Spirit of the Ordinance of 1787: Organizational Values, Voluntary Association and Higher Education in Ohio, 1803-1830, in EDUCATION IN THE OLD NORTHWEST, supra note 25, at 97-114.

${ }^{101}$ EduCATION IN OHIO, supra note 85, at 97.

${ }^{102}$ Id. at 120 .

${ }^{103}$ David B. Tyack, One Best System: A History of AmErican Urban EduCATION 3039 (1974); REISNER, supra note 34, at 319-28.

${ }^{104}$ EDUCATION IN OHIO, supra note 85, at 119-21. See supra note 34 (sources chronicling the history of the common school movement).

${ }^{105}$ Kaestle, supra note 25, at 34. See CREMIN, supra note 34 , at 175-76.

${ }^{106}$ SMITH \& SMITH, supra note 49 , at 242. See CREMIN, supra note 34 , at 173-78. Among the most prominent "friends of education" in Ohio were Catharine Beecher, Samuel Lewis, Albert Pickett, and Calvin Stowe. Id. at 175 (listing prominent friends of education in several states).
} 
The first glimmer of an organized common school movement in Ohio came in 1829 when twenty teachers met to form the Western Literary Institute and College of Professional Teachers. ${ }^{107}$ Their stated purpose was to "promote harmony, cooperation, and the diffusion of knowledge among its members, and to discuss subjects conducive to the advantage of education generally." 108 The group met regularly over fourteen years, receiving over three hundred addresses and reports that discussed all aspects of education. ${ }^{109}$ Meetings, speeches, and pamphlets published by this group evangelized the cause of public education and generated great interest among teachers, educational activists, and scholars. ${ }^{110}$ The society held annual meetings that lasted a full week and used the largest meeting rooms in the city. ${ }^{111}$

The society advocated the organization of teachers' associations, graded schools, and the creation of the office of State Superintendent of Public Instruction. ${ }^{12}$ With this agenda, the Western Literary Institute placed itself at the forefront of a politicized public school movement. At its annual meeting in 1835, the organization resolved that meetings of teachers and other friends of education should be held at the seat of state government during the legislative session. ${ }^{113}$ The advocates of public education enlisted the support of "as many recruits as they could attract, not only from the teaching profession, but also from politics and public life." 114 The Institute's "first State Convention held in Ohio in the interest of public education" was convened in Columbus on January 13, $1836 .{ }^{115}$ The General Assembly was

\footnotetext{
${ }^{107}$ CREMIN, supra note 34 , at 175 (meeting annually and attracting educational leaders from the other western states); see EDUCATION IN OHIO, supra note 85, at 360. The group was first called the Western Academic Institute and Board of Education and changed its name in 1831 to the Western Literary Institute and College of Professional Teachers. Id. at 313; REISNER, supra note 34 , at 322.

${ }^{108}$ EdUCATION IN OHIO, supra note 85, at 360. At the annual meeting of the Academic Institute in 1831, the principal address was delivered by a Dr. Bishop of Miami University who spoke of the need for improved methods of instruction and more competent teachers. To address this need, the group, now calling themselves the Western Literary Institute and Board of Education, adopted a constitution that included provision for a Board of Education. BuRNS, supra note 53, at 85 . The board was made up of honorary members, non-professional advocates of education, chosen by the society and charged with the responsibility of visiting and inspecting the schools. Id.

${ }^{109}$ EducATION IN OHiO, supra note 85, at 362.

${ }^{110} \mathrm{Id}$. at 96,115 .

${ }^{111} I d$. at 362. Prominent educators traveled to attend these meetings. Attendees included Albert Picket, Alexander Kinmont, Milo G. Williams, W.H. McGuffey (author of the famous McGuffey Reader), Samuel Lewis, Dr. Joseph Ray, Nathan Guilford, and Calvin E. Stowe. Id.

${ }^{112} I d$.

${ }^{113} I d$. at $362-63$.

${ }^{114}$ CREMIN, supra note 34 , at 176-77.

${ }^{115}$ EdUCATION IN OHIO, supra note 85, at 363.
} 
invited to attend the proceedings and Governor Robert Lucas acted as president. ${ }^{116}$ The Western Literary Institute's conventions, public meetings, teaching institutes, and pamphlets were influential in securing the 1837 appointment of Samuel Lewis as the first Superintendent of Common Schools in the state. ${ }^{117}$

In his first year as superintendent, Samuel Lewis traveled 1500 miles around Ohio, visited three hundred schools, and held countless meetings with teachers and county officials. ${ }^{118}$ Like Horace Mann, who was appointed Superintendent of Common Schools in Massachusetts in the same year, Lewis became a visible and vocal advocate of free, state-supported schooling. Like Mann, he articulated the goals of the common school movement and used his powerful intellect and persuasive speech to convert new believers to the cause of popular education. ${ }^{119}$ According to Lewis and Mann, the common school would play a central role in the development of a republican society. The school would bring together diverse groups and classes of people; it would be an engine of social mobility and economic opportunity; it would produce virtuous citizens for self-government.

It would be common, not as a school for the common people . . but rather as a school common to all people. It would be open to all and supported by tax funds. It would be for rich and poor alike, the equal of any private institution. And, by receiving children of all creeds, classes and backgrounds, ... it would kindle a spirit of amity and mutual respect that the conflicts of adult life could never destroy. ${ }^{120}$

\section{E. A Model of a Complete System of Common School Instruction for the Whole People}

The interest and excitement generated by the first state convention of the Western Literary Institute in 1836 prompted the Ohio Legislature to commission a study of European school systems. The legislature appropriated $\$ 500$ for Calvin Stowe, an advocate for a liberal system of public schools and Professor of Biblical Literature at the Lane Theological Seminary in Ohio, to study European systems of education and

\footnotetext{
${ }^{116} I d$. Governor Lucas called for an improvement in public education, the establishment of school libraries, and the election of a state superintendent. Further, he submitted to the senate a pocket edition of a College of Teachers' publication entitled "Infinite Riches in a Little Room." This edition contained the report of Calvin E. Stowe, following his return from Prussia, alongside an address by Samuel Lewis. BuRns, supra note 53, at 86. The second and third conventions were held in December 1837 and 1838, attracting increasing numbers of educators and prominent citizens from all parts of the state. Sessions were presided over by former governors, prominent judges, and educators. The proceedings were published to the General Assembly and circulated to teachers throughout the state. EDUCATION IN OHIO, supra note 85 , at 363-66.

${ }^{117}$ MILLER, supra note 24, at 11 (surviving great opposition and passing through the House by a vote of 35 to 34 ).

${ }^{118}$ EDUCATION IN OHIO, supra note 85, at 334.

${ }^{119}$ Id. at 334-35; SAMUel P. ORth, The CEnTRAlization of AdMinistration in OHIO 45 (1903).

${ }^{120}$ CREMIN, supra note 34 , at 138 .
} 
to create a report with recommendations for the legislature. ${ }^{121}$ The result was a report to the governor and legislature of Ohio in December of 1837 in which Stowe praised the Prussian system, compared the conditions of Ohio and Prussia, and discussed a model for a thorough and efficient system of education.

Stowe's report was a seminal document in the establishment of state-supported schooling in Ohio and elsewhere. The legislature ordered ten thousand copies of the report to be printed and distributed to every school district in the state. ${ }^{122}$ It was also reprinted for the legislatures of Massachusetts, Michigan, North Carolina, Pennsylvania, and Virginia. ${ }^{123}$ In his report, Stowe articulated the philosophical underpinnings, substantive content, and organizational structure of the reforms that were central to the "friends of education." His report bore the imprint of the educational thought of early republicans like Thomas Jefferson, Benjamin Rush, and John Adams, who emphasized the public purpose of education. ${ }^{124}$ It also echoed the contemporary thinking of Horace Mann and Samuel Lewis on the importance of common schooling. It further set forth the substantive content and structure for a curriculum endorsed by European educational theorists like John Henry Pestalozzi. ${ }^{125}$ Finally, the report exuded confidence in the power of centralization and bureaucracy to provide adequate resources and to assure high standards.

\section{The Public Interest In Common Schooling}

Like Jefferson and other early republicans, Stowe believed that education ought to be provided by the state because it is necessary to the political and economic survival of the state. "Republicanism," wrote Stowe, "can be maintained only by universal intelligence and virtue among the people.... [W]ithout intelligence and virtue in the great mass of the people, our liberties would pass from us." ${ }^{126}$ Universal education would enhance not only intelligence and virtue, but also citizen equality and affinity, all of which he considered essential to republican government. Stowe quoted a circular published by the Prime Minister of Prussia declaring that the national welfare depended on education. It stated:

\footnotetext{
${ }^{121}$ Stowe, supra note 14 , at $244-45$. Calvin Stowe already had planned a business trip to Europe. The legislature's commission to him directed him to collect while he was on business in Europe "such facts and information as he may deem useful to the state in relation to the various systems of public instruction and education, which have been adopted in the several countries through which he may pass, and make report thereof, with such practical observations as he may think proper, to the next General Assembly." Id.

${ }^{122}$ Id. at 246; Charles G. Miller, The Background of Calvin E. Stowe's "Report on Elementary Public Instruction in Europe,” 40 OHIO ST. ARCH. \& HIST. Q. 185 (1940).

${ }^{123}$ Stowe, supra note 14 , at 246.

${ }^{124}$ See supra notes 53-64 and accompanying text.

${ }^{125}$ John Henry Pestalozzi, born in 1746 in Switzerland, was an educator who implemented reforms in European education. His educational philosophy represented a continuation of the revolutionary influence of Rousseau and emphasized child-centered learning, striving for allround development of intellectual, moral, physical, and vocational life. For a brief summary of Pestalozzi's life, educational theory, and influence on the development of the common school, see REISNER, supra note 34, at 179-99.

${ }^{126}$ Stowe, supra note 14 , at 256-57.
} 
[T] he new system is based upon the principle, that every subject, personally free, be able to raise himself, and develop his powers freely, without let or hindrance from any other; that the public burdens be borne in common and in just proportions; that equality before the law, be secured to every subject; that justice be rigidly and punctually administered; that merit in whatever rank it may be found, be enabled to rise without obstacle; that the government be carried on with unity, order, and power; that, by the education of the people, and the spread of true religion, the general interests, and a national spirit be promoted, as the only secure basis of the national welfare. ${ }^{127}$

Stowe further pointed out that Prussia's national system of education promoted a "national spirit" by fostering in each young mind "an attachment to his native land, and its institutions." 128 Creating a sense of national identity was considered to be particularly important in the United States, where the population was becoming increasingly diverse. ${ }^{129}$ Perhaps even more important, especially in light of the 1828 election of the populist Andrew Jackson, Stowe asserted that education was also the way to avoid the "evils of an ignorant and unbridled democracy." 130 Education of the masses was, in his view, essential to the common good. According to Stowe, it was false economy and bad policy not to include appropriate provision for the poor in the scheme of common education. He wrote:

[It is] for the highest good of the State, that these minds should be withdrawn from vice and trained up to be enlightened and useful citizens, contributing a large share to the public wealth, virtue and happiness; rather than that they should come forward in life miserable criminals, of no use to themselves or the public, depredating on the property and violating the rights of the industrious citizens, increasing the public burdens by their crimes, endangering the well being of society, and undermining our liberties! They can be either one or the other, according as we choose to educate them ourselves in the right way, or leave them to be educated by the thieves and drunkards in our streets, or the convicts in our prisons. The efforts made by some foreign nations to educate this part of their population, is a good lesson for us. All the schools and houses of reformation in Prussia, do not cost the government so much as old England is obliged to expend in prisons and constables for the regulation of that part of her population, for which the government provides no

${ }^{127} I d$. at $252-53$

${ }^{128} I d$. at 255 .

${ }^{129}$ Developing a national affinity that would prevent the new republic from devolving into warring groups or anarchy was a central concern of early school advocates like Benjamin Rush and Thomas Jefferson. KAESTLE, supra note 6, at 4-7.

${ }^{130}$ Stowe, supra note 14 , at 251 . Commentators have acknowledged that universal suffrage and the election of Andrew Jackson heightened concern over public education. Reisner, supra note 34, at 325-26; Henry J. Perkinson, The Imperfect Panacea: AMERICAN FAITH IN EDUCATION 1865-1965, at 10-12 (1968). 
schools but the hulks and the jails; and I leave it to any one to say which arrangement produces the greatest amount of happiness. ${ }^{131}$

\section{The Great Object of Education: A "Thorough Development of all the Intellectual and Moral Powers"}

With regard to the content of a free education, Stowe asserted the proper goal of education to be a "thorough development of all the intellectual and moral powersthe awakening and calling forth of every talent that may exist, even in the remotest and obscurest corner of the State, and giving it a useful direction." 132 The childcentered curriculum described by Stowe was influenced by Pestalozzian reforms and proposed a dramatic change from the curricula generally in use at the time in Ohio. Stowe's model rejected the one-room schoolhouse and the Lancasterian monitorial system $^{133}$ and recommended graded classes and a progressive program of instruction.

In order to develop "every faculty of the soul, and to bring into action every capability of every kind that may exist," Stowe reported, the Prussian schools were sequenced in three distinct branches: Rudiments, Elements (elements of education to be applied), and Applications. ${ }^{134}$ In the curriculum described by Stowe, which he compiled based on his observations of a number of different schools in Prussia and central Europe, ${ }^{135}$ the first rudimentary course included logical exercises, elements of reading, elements of writing, and elements of arithmetic. Elementary instruction included continuation of these courses, and added language or grammar, geometry, and music. The third two-year course of instruction, for the 12-to-14-year-old age group, included a continuation of the "Real Instruction," applications of the elementary studies to the business of life, and concluding courses in language, drawing, and applied mathematics, such as surveying, civil engineering, etc. ${ }^{136}$ Rather than rote memorization, the curriculum emphasized conversations between teacher and student, exercising and developing the powers of observation, expression, reflection, memory, judgment, and imagination. ${ }^{137}$

\footnotetext{
${ }^{131}$ Stowe, supra note 14 , at 267-68.

${ }^{132} I d$. at 270 .

${ }^{133}$ The Lancasterian system, developed by Joseph Lancaster, used student monitors to drill students on specific lessons and skills. In this system, learning was "synonymous with memorizing" and teaching was "little more than mastery of the material to be memorized." RAVITCH, supra note 24, at 13-19 (describing in detail the Lancasterian curriculum and system as it was used in the New York City free schools during the early Nineteenth Century).

${ }^{134}$ Stowe, supra note 14 , at 246; Miller, supra note 122 , at 186.

${ }^{135}$ Stowe, supra note 14 , at 305.

${ }^{136} I d$. at $271-304$.

${ }^{137} I d$. at 276,305 . The emphasis on developing discretion brings this curriculum into sharp contrast with the curriculum commonly offered in early Nineteenth Century American schools. In the Lancasterian system, for example, using imagination was actively discouraged. RAVITCH, supra note 24, at 14.
} 
Consistent with the times, there was also great emphasis on religious instruction. ${ }^{138}$ Stowe believed that non-sectarian moral instruction based on the Bible was essential. He did not believe, however, that diversity of beliefs precluded the schools from teaching about religion and morality. He wrote:

I inquired of all classes of teachers, and men of every grade and religious faith ... in places where there was uniformity and in places where there was diversity of creeds, of believers and unbelievers, of rationalists and enthusiasts, of Catholics and Protestants; and I never found but one reply, and that was, that to leave the moral faculty uninstructed was to leave the most important part of the human mind undeveloped, and to strip education of almost every thing that can make it valuable; and that the Bible, independently of the interest attending it, as containing the most ancient and influential writings ever recorded by human hands, and comprising the religious system of almost the whole of the civilized world, is in itself the best book that can be put into the hands of children to interest, to exercise, and to unfold their intellectual and moral powers. Every teacher whom I consulted, repelled with indignation the idea that moral instruction is not proper for schools; and spurned with contempt the allegation, that the Bible cannot be introduced into common schools without encouraging a sectarian bias in the matter of teaching. ${ }^{139}$

Stowe was careful to point out that systems of free education were developing in Protestant, Catholic, and Greek Orthodox countries in Europe. ${ }^{140}$ In his view, the "three great divisions of Christendom" posed no obstacle to effective religious instruction in a public system. ${ }^{141}$ Religious instruction based on the "the life and discourses of Jesus Christ, the history of the Christian religion, in connection with the contemporary civil history, and the principal doctrines of the Christian system" could be offered without offending various sectarian beliefs. There is no hint of antiCatholic sentiment in Stowe's writing; Stowe apparently believed that the Bible could be studied "thoroughly, and systematically, and practically, without the least sectarian bias." 142

For Stowe, the most striking features of the curriculum of the Prussian system were its great completeness in subjects and its development of every aspect of the mind and character. ${ }^{143}$ Stowe thought that no subject was left out, except possibly the learning of multiple languages, which could easily be added. He felt that in the Prussian curriculum every faculty of mind was developed and exercised, including

\footnotetext{
${ }^{138}$ Miller, supra note 122 , at 187 ("Wherever we turn in early educational history, the most active teachers were trained in the seminaries, and were generally trained for the ministry.").

${ }^{139}$ Stowe, supra note 14 , at 259.

${ }^{140} I d$. at 254 (noting also that "even the Sultan of Turkey and the Pacha of Egypt, are looking around for well qualified teachers to go among their people").

${ }^{141} I d$.

${ }^{142} I d$. at 292.

${ }^{143} I d$. at 305 .
} 
"the perceptive and reflecting faculties, the memory and the judgment, the imagination and the taste, the moral and religious faculty, and even the various kinds of physical and manual dexterity."

\section{A "System" of Education: To "Secure Fidelity and Efficiency"}

Central to the program of reform that Stowe advocated was the creation of a "system" of schools. At the turn of the Nineteenth Century, a school "system" denoted a method or plan for organizing a single school. In the early years of the republic, however, Americans watched with interest as nationally organized programs of education evolved elsewhere. ${ }^{144}$ In particular, the national system devised by Frederick the Great in Prussia embodied a system of "bureaucratic thoroughness," that was the focus of much attention. It mandated compulsory attendance and punishment for parents if children did not attend school; it created a network for the training of teachers; and it defined a uniform curriculum with articulated levels of schooling. ${ }^{145}$

In his report, Stowe stressed the importance of organizational structure of a system of education that would support all aspects of the educational process, from providing an inviting place for students to study to providing well-trained and motivated teachers. ${ }^{146}$ Further, he recommended central organization under a Superintendent of Common Schools who would "do what is necessary" to attain the "great object" and "secure fidelity and efficiency." Stowe wrote that implementation of an efficient system of common school instruction would require the following essentials:

1. Teachers must be skillful, hence must be trained.

2. To be trained, teacher-training institutions must be established.

3. Adequate pay and pension systems are necessary if the state is to have the best of its population as teachers.

4. Schools must be comfortable and planned for the pupil's benefit.

5. School discipline must be maintained for the general benefit. ${ }^{147}$

Finally, Stowe declared an awakening in the world and a simultaneous effort for the spread of education, and that "sad indeed will be the condition of that community

\footnotetext{
${ }^{144}$ Carl F. Kaestle, The Evolution of the Urban School System: New York City, 1750-1850, at 161 (1973).

${ }^{145}$ GLENN, supra note 34, at 149-50; KAESTLE, supra note 144, at 161.

${ }^{146}$ Stowe, supra note 14 , at 308-15.

${ }^{147}$ Miller, supra note 122 , at 189 . Stowe wrote, "To give efficiency to the whole system, to present a general standard and a prominent point of union, there should be at least one model-teachers' seminary, at some central point - as at Columbus - which shall be amply provided with all the means of study and instruction, and have connected with it schools of every grade, for the practice of the students, under the immediate superintendence of their teachers." Stowe, supra note 14, at 309-10. He did not favor corporal punishment and believed that teachers needed to be trained in classroom management. Id. at 312 . He also believed that the system would have to be introduced gradually to win public support. Id. at 313.
} 
which lags behind in this universal march." 148 He noted that even in Russia were the "beginnings of a complete system of common school instruction for the whole people," and that many kingdoms and governments were "zealously engaged in doing what despotic sovereigns have seldom done before-enlightening and educating their people; and that too with better plans of instruction, and a more efficient accomplishment in practice the world has ever before witnessed." ${ }^{149}$ Stowe appealed to the patriotism of the Ohio Legislature, saying that the necessity of selfpreservation demanded a better education than of that provided by the despotic governments, and that a complete education of the whole people is necessary for the existence and successful maintenance of free institutions in our country.

Anticipating the argument that it would not be practically possible to create an entire system of common schools, Stowe answered that the honor of our nation and the welfare of our state depended on achieving what was already being done elsewhere:

The above system is no visionary scheme emanating from the closet of a recluse, but a sketch of the course of instruction now actually pursued by thousands of schoolmasters in the best district schools that have ever been organized.... [I]f it can be done in Prussia, I know it can be done in Ohio. Shall this object, then, so desirable in itself, so entirely practicable, so easily within our reach, fail of accomplishment? For the honor and welfare of our State, for the safety of our whole nation, I trust it will not fail. ${ }^{150}$

Stowe's report was put into the hands of teachers, educational activists, and legislators in Ohio and in other states. It not only mapped out a model for a system of common schools, but also set out a national challenge: If the United States of America was to partake in industrial progress, civilized democracy, and be on equal footing with European nations in commerce and intellectual and moral development, the establishment and success of a system of free common schools was imperative. Stowe's report made the establishment of a thorough and efficient system of free common schools a matter of national security, pride, and honor.

\section{F. The Need for a Constitutional Provision}

The delivery of Calvin Stowe's glowing report on the schools in Prussia was followed shortly by Samuel Lewis's first report to the General Assembly as the Superintendent of Common Schools. Lewis's observations of the existing Ohio schools told the legislature a story of miserable and inefficient schools, without trained teachers, adequate buildings, or funds. ${ }^{151}$ Like Stowe, Lewis extolled the

${ }^{148}$ Stowe, supra note 14 , at 270.

${ }^{149} I d$. at 254 .

${ }^{150} I d$. at 307.

${ }^{151}$ ORTH, supra note 119 , at 45. 
virtues of a state-organized system of free common schools and urged the passage of new legislation. ${ }^{152}$

The challenge was clear. And the legislature responded, passing the school law of 1838, which gave some organization and leadership to the system. ${ }^{153}$ Thus, Ohio became an early leader in the establishment of a state-supported free system of common schools.

It would soon become clear, however, that gains made in one legislative session could easily be lost in another. For example, the 1837 law establishing the position of Superintendent of Common Schools passed by a slim majority in the House of Representatives, "with nineteen Whigs and sixteen Democrats voting yes and fifteen Whigs and nineteen Democrats voting no." 154 Only three years later, however, when Superintendent Samuel Lewis fell ill and resigned, the legislature could not be persuaded to continue to support a state officer for education. The position of State Superintendent was abolished and its duties were relegated to a clerk for the Secretary of State. ${ }^{155}$ Thereafter, the legislature passed a succession of amendments to the law of 1838 and collateral acts, undermining progress toward a state system of free common schools and making the school laws "almost perfectly unintelligible to men of ordinary capacity and research." 156 Frustration with the state of disarray of

${ }^{152} I d$. at $45-46$. Specifically, he suggested that schools be made free; that the number of school officers be decreased but their powers increased; that the school districts be made uniform with fixed boundaries; that the township be made the unit of administration and an elected township board be empowered to adopt uniform textbooks; that a school fund be created by direct tax; that the office of county superintendent be established; that the county courts appoint boards of examiners to examine teachers and that a normal school be established for the training of teachers; that the powers of the state superintendent be increased to give him centralized control over the entire system; and that a law should be created to regulate the period of time in which schools were to be in session and for compulsory attendance of all children. Id. The agenda mapped out by Lewis formed the basic program of school development that would be implemented over the next century. It should be noted that the common schools of other states, including Massachusetts and New York, were probably in no better condition than the schools of Ohio during this era. EDUCATION IN OHIO, supra note 85 , at 98 .

${ }^{153}$ See 1838 Ohio Laws 21, 36 (An Act For The Support And Better Regulation Of Common Schools, And To Create Permanently The Office Of Superintendent). See also BuRNS, supra note 53, at 168-69 ("In this law the duties of the State Superintendent are prescribed, doubtless, to a great extent, the result of the incumbent's thought and experience: to furnish the auditor of state annually an enumeration of all white youth between four and twenty-one years of age; collect all information deemed important and report the value of all school lands and the amount of funds due each township; furnish forms for all reports to those who were to make them; have general superintendence over all property given for the purpose of common school education; cause prosecutions in the courts for the purpose of common school education; cause prosecutions in the courts for all 'waste committed or about to be committed, either by the misuser or nonuser,' and require reports of all persons having school property in charge.").

${ }^{154}$ CREMIN, supra note 34 , at 173.

${ }^{155}$ BuRNS, supra note 53, at 169.

${ }^{156} I d$. at 74 (containing excerpts from reports by the secretary of state and county auditors on the condition of the school laws prior to the Act of 1853). Laws enacted between 1840 and 
the school laws inspired many education officers to call for "[a] law in relation to common schools, whose provisions are plain and easy to be understood .... [T] he Legislature would meet the wishes of the people, if they would repeal the whole of the law, and enact another of less doubtful interpretation." 157

The incoherence of the state law relating to education was a result of a cacophony of voices in the legislature, each seeking to advance programs that would directly benefit the residents of their own districts. In 1836, there were 7,748 school districts and 38,740 school officers. ${ }^{158}$ Piecemeal legislation passed to satisfy individual officers and districts did little to improve standards or make free education more generally available. ${ }^{159}$ Further, the common school agenda remained controversial.

Opposition to the establishment of a state-wide system of common schools generally coalesced around two issues: taxation and control. Although most people agreed that literacy was important for self-advancement and the existence of democracy, and that government should make some kind of commitment to elementary education, many were opposed to taxing everyone to make common schools entirely free. ${ }^{160}$ Some argued that the "property of the State ought to be no more bound to educate the youth of the State than to clothe and feed them."161 Many people did not want to pay for the education of other people's children; farmers, in particular, wanted as little government as possible and opposed property taxes for schools. ${ }^{162}$ In rural areas where people were highly self-sufficient, the need for schools supported by general taxation was not as evident as in the urban districts where residents were more convinced that institutions were needed in the face of industrialization and increasing lack of social discipline. ${ }^{163}$ Thus, opposition to

1850 concerned only the district school and did not provide for secondary or higher education institutions as part of the state system. Also, there was no provision for town or city schools or a graded school system until 1847 . However, many of the laws enacted while Lewis was in office stayed on the statute books and others were revived when the new constitution was adopted in 1851. "That instrument [the 1851 Constitution] vindicated his services and confirmed his title of "father of the free school system of Ohio."' C.B. Galbreath, Samuel Lewis, in EduCATIONAL History OF OHIO 421(James J. Burns ed., 1905).

${ }^{157}$ BuRNS, supra note 53 , at 75 .

${ }^{158}$ ORTH, supra note 119 , at 44.

${ }^{159}$ James W. Taylor, A Manual of the Ohio School System Consisting of AN Historical View of Its Progress, and a Republication of the School Laws in Force $187-205$ (1857)(summarizing school laws from 1831 to 1853 , noting particularly the accomplishments of the 1838 and 1853 laws and the confused state of the laws passed in the interim years).

${ }^{160}$ See Kaestle, supra note 25 , at 35.

${ }^{161}$ TAYLOR, supra note 159 , at vi.

${ }^{162}$ Kaestle, supra note 25 , at 34.

${ }^{163}$ Id.; see MILLER, supra note 24, at 30-32 (describing the Akron Act of 1847, which created the first efficient system of public schooling in Ohio at a city-wide level and became the model for other urban areas). 
taxation for education, though widespread, was strongest in southeastern and rural districts of the state. ${ }^{164}$

Opposition to taxation for education also came from those who objected to increasing state power and centralization of control over the schools. Across the state, thousands of school officers operated with little regulation or supervision. These school officers and many of the people in the various districts had become invested in the diverse local arrangements that they had made for their children's education.

Ohio was a frontier community, settled by a class of people who were compelled to be self-reliant and to solve their own problems, educational as well as others. It was a heavily timbered area, where means of communication were lacking or extremely difficult at best. Because of these natural conditions, it would have been a difficult task to establish any general system of control or supervision over education in the early period even if there had been a wholehearted desire to do so. By the time means of communication had become simplified through a system of public roads and canals, the people had become accustomed to attending to their educational needs and were somewhat resentful toward any outside influences or suggestions. ${ }^{165}$

Rural localists opposed interference with district schools, and conservative democrats opposed centralization because it was associated with the Whig Party. ${ }^{166}$ Some immigrant groups also felt threatened by the movement for state systems of publicly funded common schools. Foreign-born citizens feared a uniform state system would erode or wipe out support for their diverse institutions. ${ }^{167}$ In spite of the competition and tension among various ethnic and religious groups for the limited school funds, many preferred the status quo-without state funding or state control. ${ }^{168}$

During the first half of the Nineteenth Century, a majority of the population opposed "taxing everyone to make schooling entirely free." 169 The battle to win acceptance of the idea that "everyone had a stake in common schools and therefore that everyone ought to pay for them" 170 was one that required an organized effort to win the public over to a new faith in power, possibility, and need for free universal

${ }^{164}$ Kaestle, supra note 25, at 35.

${ }^{165}$ EduCATION IN THE STATES, supra note 74 , at 949.

${ }^{166}$ Kaestle, supra note 25, at 34. But see PERKINSON, supra note 130, at 10-12 (describing Jacksonian democracy contributing to the momentum of the common school movement by reinforcing the idea that the schools might secure a more general equality).

${ }^{167}$ Professor Kaestle points out that within immigrant groups there was disagreement about the role of schooling: some favored rapid Americanization through public schools, while others preferred to maintain their own cultural institutions. Kaestle, supra note 25, at 37.

\footnotetext{
${ }^{168} I d$.

${ }^{169} I d$. at 33 .

${ }^{170} I d$.
} 
education. In Ohio, the organized effort that had begun with the founding of the Western Literary Institute in 1829 continued through the next two decades unabated. ${ }^{171}$ Although the Western Literary Institute had its last meeting in the early 1840 s, teachers, preachers, and other friends of education reorganized in 1847 as the Ohio State Teachers' Association. ${ }^{172}$

The Teachers' Association was unstinting in its effort to sway public opinion. Recognizing that taxpayer opposition to public schools was their most significant obstacle, the Teachers' Association chose to emphasize "the importance, practicability and economy" of a reorganized system of free common schools. ${ }^{173}$ The Teachers' Association held public addresses and conducted institutes across the state advocating better organization and graded, free schools. ${ }^{174}$ In 1848, for example, the Teacher's Association made arrangements for holding Teachers' Institutes in every county in the state. ${ }^{175}$ The Association then hired "teachers of ability and experience" to visit the counties and give a free one-week course of instruction to the teachers of the county "provided the county examiners, teachers themselves, and friends of education, should co-operate in the measures proposed" by the Teachers' Association. ${ }^{176}$

The Teachers' Association worked with missionary zeal to convert the public to the cause of common schooling. The Executive Committee of the Teachers' Association wrote several hundred letters "to public men and private citizens, in the counties designated, asking their influence and effort in behalf of the plans of the committee." 177 They also wrote letters to the clergy in hundreds of different churches, asking the preachers to use their pulpits to speak about the importance of common schooling. ${ }^{178}$ When the Ohio Legislature failed to provide for a Superintendent of Common Schools, the Teachers' Association appointed its own "Common School Missionary" to serve as general agent for the Association and to promote the cause of common schooling. ${ }^{179}$

\footnotetext{
${ }^{171}$ EDUCATION IN OHIO, supra note 85, at 11-117.

${ }^{172}$ BuRnS, supra note 53, at 93-94. The goals of the organization, as articulated by the chairman in an 1848 address, included elevating teachers and reorganizing the schools of the state. These goals were to be accomplished by addressing citizens publicly and preparing "the public mind for a school system for our State unparalleled for the liberality of its provisions, the wisdom of its measures and the harmony and efficiency of its operation." Id.

${ }^{173}$ EducAtion in OHio, supra note 85, at 365-66 (quoting M.F. Cowdery, Report of the Executive Committee of the State Teachers' Association to the State School Department (December 1848) (emphasis added)).

${ }^{174}$ Id. at $99,117-18$.

${ }^{175} I d$. at 365 .

${ }^{176} I d$. at 366 (emphasis added).

${ }^{177} I d$.

${ }^{178} I d$.

${ }^{179}$ Lorin Andrews, who was the principal of Massillon High School, resigned his post and agreed to act as the general agent of the OSTA without the promise of any salary. TAYLOR, supra note 159 , at 377 . In this capacity, he traveled extensively around the state, conducting
} 
The Association's goal was to create a "public sentiment which will be satisfied with nothing less than an educational system, which will afford to every child in the State, a proper physical, intellectual, and moral development." ${ }^{\text {"180 }}$ In 1850, it sponsored hundreds of practical educational addresses to large assemblies of citizens in various parts of the state, reaching thousands of citizens. ${ }^{181}$ Teaching Institutes for 3,000 teachers were conducted in 1850. According to Lorin Andrews, the Association's Common School Missionary, these Institutes increased the teachers' "love for their profession," and "their zeal for the improvement of common schools." The Institutes made the teachers "efficient, intelligent missionaries, ... better qualified, not only to teach, but also to preach school.",182

The work of the Teachers' Association was now supported by a national network of education advocates who spoke, wrote, and lobbied for the establishment of universal, free schooling. The common school ideal was honed and disseminated through a number of journals and reports from Ohio and from activists in other states. Horace Mann, the Massachusetts educational advocate who is often called the "father of the common school," published the first of twelve annual reports on the schools of Massachusetts in $1836 .{ }^{183}$ The same year, he began publishing the Common School Journal. ${ }^{184}$ Journals in other states, including the Ohio School Journal, which began publication in 1846, spread the "gospel of good schools." 185

School reformers sought to shift the responsibility for education from the parents to the community, and from the local districts to town-wide, county, and state officials. ${ }^{186}$ They emphasized that education left in the hands of parents and diverse groups resulted in disparities in the amounts and types of schooling that children received and that this violated the principles and necessities of democracy. ${ }^{187}$ Education advocates now had a specific vision of the school and the role of the school in society. ${ }^{188}$ These activists self-consciously began using the term "common

teaching institutes and promoting the cause of free public schooling. Eventually, the teachers who were members of the association paid him. EDUCATION IN OHIO, supra note 85, at 338, 381.

${ }^{180}$ EdUCATION IN OHIO, supra note 85, at 380-81 (quoting report of Lorin Andrews to State Teachers' Association).

${ }^{181} I d$. (quoting Andrews report) (reporting also that their appeal had reached "not less than sixty thousand citizens of Ohio").

${ }^{182} I d$. at 381 (quoting Andrews report) (emphasis added).

${ }^{183}$ MASSACHUSETTS BOARD OF EdUCATION, ANNUAL REPORT, TOGETHER With THE ANNUAL REPORT OF THE SECRETARY OF THE BOARD 48 (1837) (Horace Mann, Secretary) [hereinafter MASSACHUSSETTS REPORT].

${ }^{184}$ REISNER, supra note 34 , at 321.

${ }^{185} I d$.

${ }^{186}$ EDUCATION IN THE STATES, supra note 74, at 39-45.

${ }^{187}$ Id. at $39-40$.

${ }^{188}$ See, e.g., GLENN, supra note 34, at 4-5 (describing the "Common School Agenda" as an "effort to create in the entire youth of a nation common attitudes, loyalties, values, and to do so under central direction by the state"); REISNER, supra note 34, at 325-26 (noting that the 
school" to refer only to free public schools; and began using the term "private" school to refer to those where parents paid tuition. ${ }^{189}$

The term "common school" was now understood to mean "common, not as inferior ... but as the light and air are common." 190 Free schooling should not be limited to children from poor families, because the existence of charity schools "tends to create distinctions hostile to the character and spirit of our institutions." Knowledge was viewed as part of the common property of the people, which could and should be diffused broadly. Common schooling-which required the schooling of rich and poor together-was seen as essential to the creation of economic opportunity and the development of democratic institutions. According to Horace Mann, education was "beyond all other devices of human origin, [the] great equalizer of conditions of men - the balance wheel of the social machinery." 192 Education would empower the poor and give them the opportunity for economic advancement and social mobility. Further, education was considered to be part of the rights of the people. According to one Ohio educational activist:

The truth is, the State, as such, has a vital interest in this matter of popular education; and is bound in her sovereign capacity, to look at it. All her youth have a God-given right to such an education, moral and mental, as constituted a perfect manhood; and therefore, they have a claim, not only upon their parents, and the State, but upon the entire property of the State to furnish them with all the requisite facilities for attaining to such a degree of intellectual culture as will enable them rightly to comprehend their duties and relations to God, to the State and to their fellow men. ${ }^{193}$

Three years after the founding of the Teachers' Association, and following hundreds of public addresses, more than seventy towns and cities established free graded schools. ${ }^{194}$ By 1849 public sentiment in favor of free universal public schooling was strong. But education activists understood that public support was fragile and that more work remained to be done. In a report published in the Ohio Journal of Education, the Chairman of the Ohio State Teachers' Association proclaimed their successes in 1849 to be merely a beginning. He declared:

advocates of the common school movement were educated citizens and community leaders who, after the victory of Andrew Jackson, "saw clearly the imperative need" for universal education in a "country where all had equal influence at the polls"); BINDER, supra note 34, at 40 (describing the leaders of the common school movement as "solid, moderate men, totally committed to a society of morality and equal opportunity and totally convinced that their cause held the key to attaining it").

${ }^{189}$ SMITH \& SMITH, supra note 49 , at 248.

${ }^{190}$ Kern Alexander, The Common School Ideal and the Limits of Legislative Authority: The Kentucky Case, 28 HARV. J. ON LEGIS. 341, 356 (1991).

${ }^{191}$ TAYLOR, supra note 159 , at vi.

${ }^{192}$ MASSACHUSETTS REPORT, supra note 183.

${ }^{193}$ TAYLOR, supra note 159 , at viii.

${ }^{194}$ BuRNS, supra note 53, at 95. 
[The year 1849 is] a forerunner, a kind of John the Baptist, crying in the wilderness and making paths straight, for that more glorious and more comprehensive system of universal free education, which before many moons shall wax and wane, like the impartial dews of heaven will distil its blessings alike generously upon every son and daughter of this broad State. ${ }^{195}$

In 1849, education activists managed to push a bill through the legislature to establish some of the reforms they favored. The bill was passed so late in the session, however, that no appointments were made under its provisions and the act never went into operation. ${ }^{196}$ The need for permanent and unassailable provisions for common schooling had become clear. At the semi-annual meeting of the Teachers' Association in July of 1850, the assembled teachers recognized that legislation could not establish the common school ideal. Now, after more than twenty years of lobbying for legislative action, campaigning through letters to newspapers, public lectures, letters to prominent citizens, and teaching institutes, the Teachers' Association passed a resolution declaring that the "principle that common school education should forever be made free to every child in the State, should be incorporated in the constitution." 197

\section{G. The Constitutional Convention of 1850-51: A Common School Mandate}

On May 6, 1850, delegates to the Convention for the Revision of the Constitution of the State of Ohio gathered in Columbus to debate the terms of a new constitution for the state. Over the course of the next ten months, the seven members of the Standing Committee on Education presented several drafts of proposed education provisions. ${ }^{198}$ The debates on the specific wording of the provisions were lively. Notably, however, the education activists had succeeded in capturing the rhetorical high ground. In every session, the idea that an education ought to be provided to every child in the state was assumed. Free common schooling was presented and accepted as a matter of patriotism, economic urgency, and democratic necessity. Moreover, it had become a moral imperative. One delegate exhorted the assembly:

[I]n our land of liberty, all may be competitors on the great theatre of talent and advancement, knowledge and aggrandizement; each in his turn may be a philosopher, an orator, a sage, or a statesman. Intelligence is the foundation stone upon which this mighty Republic rests-its future

\footnotetext{
${ }^{195}$ EducAtion IN OHIO, supra note 85, at 118 (quoting report of the State Teachers' Association).

${ }^{196} I d$. at 338 .

${ }^{197} I d$. at 377 (emphasis added). They further resolved "that it is the opinion of this Convention, that the organic law of every State should guarantee a free education to all the youth of the State, and provide for the establishment of schools in which the same shall be communicated." TAYLOR, supra note 159, at 377 (quoting the resolution of the semi-annual convention of the OSTA in 1850).

${ }^{198}$ The seven members of the Standing Committee on Education included Harmon Stidger, Otway Curry, Samuel Quigley, James W. Taylor, Jacob J. Greene, A.G. Brown, and John A. Smith. TAYLOR, supra note 159, at 211.
} 
destiny depends upon the impulse, the action of the present generation in the promotion of literature. Will we not, are we not, as patriots, bound in solemn duty to use our energies, our influence to forward this greatest of interests to present and future generations; and especially will the great State of Ohio fall short in so mighty an enterprise - so essential and indispensable a duty? ${ }^{199}$

\section{A "Thorough and Efficient System of Common Schools" for All Children}

Every draft presented by the Standing Committee on Education contained language calling for a "thorough and efficient system of common schools." During the entire debates, there was no expression of opposition to the basic concept of tax-supported common schooling for every child in the state. ${ }^{201}$ The education activists had worked long and hard to create a "strong public sentiment, which will demand a school system for our State, unparalleled for the liberality of its provisions, the wisdom of its measures, and the harmony and efficiency of its operations." 202 And they had succeeded.

The first report submitted by the Standing Committee on Education in July 1850 contained four provisions: the first provided for an elected State Superintendent of Common Schools; the second required the General Assembly to "encourage, by suitable means, the promotion of moral, intellectual, scientific, and agricultural improvement" and to safeguard funds derived from the federal land grants for those purposes; the third required the General Assembly to "secure a thorough and efficient system of common schools, free to all the children in the state"; and finally, the fourth prohibited any religious sect or party from "ever hav[ing] exclusive right to, or control of any part of the common school funds of the state." ${ }^{203}$ During the

${ }^{199} 2$ DeBATES OF 1850-51, supra note 3, at 14 (remarks of Delegate Samuel Quigley) (Dec. $5,1850)$.

${ }^{200}$ The full text of all three drafts submitted by the Standing Committee are reprinted here in footnotes 203 and 211.

${ }^{201}$ Delegate Ledbetter pointed out, however, "our common school system is not without its enemies." He cautioned the delegates not to push for a constitutional provision that would require a minimum school term because of the voter opposition that such a provision might face. 2 DEBATES OF 1850-51, supra note 3, at 703.

${ }^{202}$ TAYLOR, supra note 159, at 380 (quoting Lorin Andrews's address to the Ohio State Teachers' Association).

${ }^{203} 2$ DEBATES OF 1850-51, supra note 3, at 693-94. The full text of the language submitted is as follows:

Sec. 1. The General Assembly shall provide for the election, by the people, of a superintendent of common schools, whose term of office, duties and compensation, shall be prescribed by law; and shall provide for the election or appointment of such assistants, or other officers as may be found necessary, prescribe their duty, term of office, and compensation.

Sec. 2. The General Assembly shall encourage, by suitable means, the promotion of moral, intellectual, scientific and agricultural improvement.

The proceeds of the sales of all lands that have been, or may hereafter be granted by the United States for educational purposes, and all lands or other property given by 
course of the debates, these four provisions would eventually be whittled down to

individuals, for educational purposes, and all lands or other property given by individuals for like purposes together with the surplus revenue deposited with this State by the United States (until reclaimed) shall be, and forever remain, a permanent and irreducible fund; the interest and income therefrom, shall be faithfully applied to the specific objects of the original grant, gift or appropriation.

Sec. 3. The General Assembly shall make such provision by taxation, and other means (in addition to the income arising from the irreducible fund) as will secure a thorough and efficient system of common schools, free to all the children in the state.

Sec. 4. No religious sect, or party, shall ever have exclusive right to, or control of any part of the common school funds of this State.

A report from the minority of the Standing Committee on Education contained six sections. The minority report was endorsed by only one member of the committee, Delegate Otway Curry. The provisions he proposed differed from the majority recommendations primarily in requiring the state to provide teacher training institutes (called Normal Institutes), requiring a minimum school term of 6 months per year, and specifically allowing race-segregated education. The full text of the minority report is as follows:

Sec. 1. Religion, morality, and knowledge, being essentially necessary to good government and the happiness of mankind, schools and the means of instruction shall forever be encouraged by legislative provision not inconsistent with the rights of conscience.

Sec. 2. It shall be the duty of the General Assembly to provide, by law, that the principal of all funds arising from the sale of lands heretofore or hereafter granted or donated, from any quarter, or educational purposes, together with the principal which may be realized from donations of personal property and money for like purposes, and the surplus revenue deposited with this State by the United States (until reclaimed) shall be preserved inviolate and undiminished; and that the interest and income arising from such funds shall be faithfully applied to the object of the original gift or grant: appropriate all or only a part of the proceeds of the surplus revenue to educational purposes.

Sec. 3. The General Assembly shall provide for the election of a superintendent of schools and seminaries of learning under the care and patronage of the State. They may also provide for the election or appointment of such assistant superintendents or other officers as may be necessary to carry into effect a thorough and uniform system of common school education; and they shall prescribe by law the terms of office, compensation, powers and duties, of all officers elected or appointed under the authority of this section.

Sec. 4. The General Assembly shall provide by law a system of common schools, and permanent means for the support thereof, by which a school shall be kept up in each school district in this State not less than six months in each year, and which shall be open to youth of all classes, under such regulations as may be prescribed by law: Provided, That black and mulatto youth shall not attend the schools for white youth, unless by common consent.

Sec. 5. Provision shall be made by law for the establishment and support of as many Normal Institutes as the General Assembly may find to be necessary for the thorough instruction of professional teachers of the common schools of this State; and all persons applying to any of said institutes for admission and instruction, shall be required, before admission, to give such assurance as may be specified by law of their intention to devote themselves to teaching as a profession.

Sec. 6. No religious sect or party shall ever have exclusive right to, or control of, any part of the common school fund, or of any of the schools, seminaries, or institutions of learning, under the care or patronage of this State. 
two, but the essential provisions requiring the General Assembly to provide for a "thorough and efficient system of common schools" and the provision prohibiting religious sects from controlling the school fund survived virtually unchanged.

The debate quickly became mired, however, in issues that have haunted the public schools since their inception: money and race. Some delegates wanted to add a provision requiring a sum certain to be raised each year for schooling by the legislature. ${ }^{204}$ After various proposals on exactly how much money should be raised each year, the delegates decided that the exact amount of funding was a matter better left to the legislature. ${ }^{205}$ The delegates also engaged in heated discussion on a motion to insert the word "white" to make schooling "free to all white children in the state."206 It was argued that public sentiment would not support taxation for schooling for "the colored race" and that providing schooling for black children would encourage unwanted immigration. ${ }^{207}$ Delegate Bates responded with an argument based on the importance of the universality of common schooling. His argument captured some of the missionary zeal of the common school movement, demonstrating that schooling was considered both an economic and moral issue:

By the insertion of the word "white" you have declared that a certain class shall not receive any of the benefits arising from the common school fund. View this question - as you will — as a matter of morality or political economy, a question of right or expediency, the State would materially suffer if a provision to exclude any class of children from the benefits of the common schools, should be engrafted in the new Constitution. The experience of the past has shown that morality and virtue keep pace with education and that degradation and vice are the inevitable results of ignorance. Good policy, humanity, and above all, the spirit of the Christian religion, demands that we should provide for the education of every child in the State. ${ }^{208}$

The motion to limit education to white children was defeated, but the debate had taken up the entire morning. ${ }^{209}$ At the end of the day, the report of the Standing

\footnotetext{
${ }^{204} 2$ DEBATES OF 1850-51, supra note 3, at 13-20.

${ }^{205} I d$.

${ }^{206} I d$. at 11-12. Delegate Sawyer moved on four separate occasions to insert the word "white" into the provisions pending. Id. at 11, 699, 704, 705. Each of his motions was defeated by a fairly substantial margin. $I d$. at $13,699,705$. In the first debate on whether schooling would be provided to black children, some delegates argued that providing education would encourage black immigration. Other delegates felt it necessary to educate poor black children so they might not become pests on society. Id. at 11-12.

${ }^{207} I d$. at $11-12$.

${ }^{208} I d$. at 13 .

${ }^{209} \mathrm{Id}$. at 13. A substitute amendment to require that schools be segregated by race was also defeated. Id. Ohio statutes already permitted separate schooling for the races. See Ohio ex rel. Directors of Eastern and Western School Districts of Cincinnati v. City of Cincinnati, 19 Ohio 178 (1850).
} 
Committee on Education was recommitted to the committee for further revisions. ${ }^{210}$ Nevertheless, by the end of the first day of debate on the education clauses, it was already clear that the vision of schooling that would be incorporated into the Constitution was the common school ideal: universal, free, non-sectarian education for self-government, enlightenment, and economic advancement.

On February 19, 1851, the Standing Committee's second report was presented and read by Committee Chair Harmon Stidger. ${ }^{211}$ Like the committee's first report, its second report contained provisions requiring the General Assembly to safeguard funds derived from the federal land grants for educational purposes, requiring the General Assembly to "secure a thorough and efficient system of common schools," and prohibiting any religious sect or party from "ever hav[ing] exclusive right to, or control of, any part of the common school funds of the state." ${ }^{212}$ These core ${ }^{210} 2$ DEBATES OF $1850-51$, supra note 3 , at 17 . In the afternoon session, one of the
members of the Standing Committee on Education, Delegate Otway Curry, gave notice that he
had prepared a minority report with alternative proposed language and that he would move to
strike all of the provisions recommended by the committee and substitute his own. Id. at 17 .
The frustration of the delegates, who had spent the entire day debating the provisions of the
majority report, was apparent. Rather than hammer out all of the differences between the two
reports in the general session, the education provisions were recommitted to the committee for
further revisions. Id. at 20 .

${ }^{211} I d$. at 663 . In a later session, Delegate Otway Curry asserted that he had not been informed of the meeting that produced the second report. Id. at 710. The text of the second report was as follows:

Sec. 1. The principal of all funds, arising from the sale or other disposition of lands, or other property granted or entrusted to this State for educational and religious purposes within the same, shall forever be preserved inviolate and undiminished, and the interest and income, arising therefrom, shall be faithfully applied to the specific objects of the original grants or appropriations, and no law shall ever be passed, preventing the poor within the several counties, townships and districts of the State from an equal participation in the schools, academies, colleges and universities, endowed wholly, or in part, from the revenues arising from donations, made by the United States for the support thereof, and the same shall be open to scholars, students and teachers of every grade, without any distinction or preference whatever, contrary to the intent for which said donations were made.

Sec. 2. The General Assembly shall provide for the perpetuation of the Board of Trustees of the Ohio and Miami Universities, and the exercise of visitorial powers, and shall also provide for the suitable superintendence of the common schools of the State. Sec. 3. The General Assembly shall make such provisions, by taxation or otherwise, as with the income arising from the school trust funds, will secure a thorough and efficient system of common schools throughout the State, and place the means of instruction in the common branches of education for a suitable portion of each year within the reach of all the children therein, of suitable age and capacity for learning. Provided that no religious or other sect or sects shall ever have any exclusive right to, or control of, any part of the school funds of the state.

Sec. 4. The General Assembly may by suitable provisions aid and encourage the formation of institutes and departments for the training of professional teachers, and affording instruction in agricultural and other practical sciences, under such regulations and conditions, as may be deemed expedient.

${ }^{212} I d$. at 663 . 
provisions, pared down to the bare bones, were the ones ultimately incorporated into the 1851 Constitution. Additional provisions of the second report, calling for the State to establish institutes for training professional teachers, to support state universities, and to support a superintendent of common schools, were rejected. ${ }^{213}$

2. Eradication of the Greatest Impediment to the Advancement of the Cause, "[T] he rivalry of schools created by different sects"

The new provisions marked a rejection of the status quo in education in Ohio. In adopting the provision for a "thorough and efficient system of common schools," the delegates rejected the patchwork of diverse schooling arrangements that existed across the state in favor of the common school vision. Delegate Reemelin explained that "no community in the world" had done as much as Ohio to try to improve education, but there had been a great impediment to the advancement of the cause"the rivalry of schools created by different sects." 214 The new educational provisions abandoned competition among sects and among a variety of small districts in favor of a single, statewide system.

During the debates, no delegate offered any argument in favor of the diverse educational arrangements that existed in Ohio at the time. No one made any plea for supporting sectarian education either. Instead, the delegates seemed concerned that the language of the proposal did not make it clear enough that the common schools would not be used for proselytizing. Delegate Thompson proposed an amendment to Section 3 that would add the words, "nor shall the rights of conscience be in any case interfered with." ${ }^{215}$ The object of such an amendment, he said, was to "secure that no religious sect shall, in any manner control the dispensation of the school funds of the State." ${ }^{\prime 16}$ On the suggestion that such a sentiment was amply covered by the Bill of Rights ${ }^{217}$ Delegate Reemelin responded that:

${ }^{213} I d$.

${ }^{214} I d$. at 17.

${ }^{215}$ Id. at 699 .

${ }^{216} I d$.

${ }^{217}$ Among the provisions in the Ohio Constitution's Bill of Rights, Article I, Section 7 provides as follows:

All men have a natural and indefeasible right to worship Almighty God according to the dictates of their own conscience. No person shall be compelled to attend, erect, or support any place of worship, or maintain any form of worship, against his consent; and no preference shall be given, by law, to any religious society; nor shall any interference with the rights of conscience be permitted. No religious test shall be required, as a qualification for office, nor shall any person be incompetent to be a witness on account of his religious belief; but nothing herein shall be construed to dispense with oaths and affirmations. Religion, morality, and knowledge, however, being essential to good government, it shall be the duty of the General Assembly to pass suitable laws, to protect every religious denomination in the peaceable enjoyment of its own mode of public worship, and to encourage schools and the means of instruction.

OHIO CONST. art. I, $\S 7$. 
$[\mathrm{T}]$ he provision in the bill of rights was in reference to grown up men, but [this] amendment ... was a provision in favor of children. The object was that when they came to the public schools, they shall not be driven away by attempts to teach any peculiar religious tenets or prejudices. It was obviously possible that the common schools might be used for purposes of inculcating peculiar religious doctrines, and thus their object might be perverted and their good effects destroyed. ${ }^{218}$

The amendment initially passed. ${ }^{219}$ In a later session, however, Delegate Smith moved to strike "nor shall the rights of conscience be in any case interfered with." The continued debate reflects the delegates' awareness of the sensitivity of the issue. One delegate stated that he believed the friends of education would agree that this provision should be stricken and that its addition would be the source of more difficulty than "anything which the constitution contains."220 Delegate Reemelin argued that the provision should be left in because mixing religion with state education will not only subtract from its economy and efficiency, but will inevitably result in the destruction of the system. He stated:

$[T]$ o secure the existence, efficiency and usefulness of the common school system of the state of Ohio for twenty years to come, [they] had better leave this provision in. If it is thrown out, there is infinite danger that such quarrels as we have had here in this city will be excited all over the State. In Cincinnati and in New York divisions have arisen which threatened to destroy not only the usefulness of the schools, but to disturb the peace of society. It is not for me to say how far the jealousies that give rise to the disturbance had any real foundation. The fact that they did exist is notorious and it is equally true that in New York, they were healed by a provision like this. ... It is our duty to lay the foundation of a system capable of expanding itself as the State advances, and of supplying all its wants; and to establish one that shall grow with the growth, and strengthen with the strength of the state, will be far better than to build up a hasty fabric, more rapidly than is required, to fall by its own weight before it acquires the strength to stand alone. ${ }^{221}$

The sentiment of the delegates resonated with the message of the common school crusaders: Sectarianism weighed down the system by creating tension and disunity.

Using the schools to proselytize for any specific sect, according to the delegates, would run counter to the common school concept which envisioned the school as a classless, non-sectarian community that would build citizens who could live in

${ }^{218} 2$ DeBATES OF 1850-51, supra note 3, at 699.

${ }^{219} I d$.

${ }^{220} I d$. at 711 . There is no further evidence in the debates on the position of various friends of education on this issue. The crusaders of the common school movement certainly believed, however, that education should inculcate morality and virtue; they might certainly have opposed a provision that could be interpreted as giving the child a right of conscience to object to the subject matter prescribed by the school.

${ }^{221} I d$. 
harmony and govern themselves without religious conflict and violence. ${ }^{222}$ But, on the other hand, could a school operate effectively if each child had a right of conscience to object to the content of instruction? The debate on these issues undoubtedly could have gone on for days. The issues were raised, however, on the hundred and twenty-third day of the convention while a motion to add temperance language to another constitutional provision was pending. ${ }^{223}$ The discussion was short and there was some confusion in the voting on the motion to strike the provision. The final report of the convention included the language, but it was stricken from the section when put to the voters of Ohio for ratification. ${ }^{224}$ Nevertheless, the delegates' intention that its "thorough and efficient system of common schools" would be non-sectarian was clear. ${ }^{225}$

\section{The Ultimate Outcome: A Mandate to the General Assembly to Provide Quality Education}

The proposed constitutional provisions would require a fundamental change in the way that education was provided; they would require the creation of a statewide system of common schooling that would replace the existing piecemeal educational arrangements. Recognizing that the new constitutional language would require change, many of the delegates were concerned about whether the public would be willing to support a new system. Much of the debate centered on how much change the public would be willing to support and whether the changes should be mandated by the General Assembly rather than the Constitutional Convention. As the debate turned to a discussion of the proposed language of the common school provision, there was tension between those who wanted a more specific mandate to the General Assembly and those who favored giving the General Assembly discretion to phase in a new educational system over time.

The proposed language of the common school provision was:

The General Assembly shall make such provisions, by taxation or otherwise, as with the income arising from the school trust funds, will secure a thorough and efficient system of common schools throughout the State, and place the means of instruction in the common branches of education for a suitable portion of each year within the reach of all the children therein, of suitable age and capacity for learning. Provided that no religious or other sect or sects shall ever have any exclusive right to, or control of, any part of the school funds of the state. ${ }^{226}$

\footnotetext{
${ }^{222}$ See, e.g., CREMIN, supra note 34 , at 138-39.

${ }^{223} 2$ DEBATES OF 1850-51, supra note 3, at 710.

${ }^{224} I d$. at 711 (passing the report on February 25, 1851 by a vote of 54 to 37, with the words "nor shall the rights of conscience be in any way interfered with," and then referring it to the
} committee on Revision, Enrollment, and Arrangement).

${ }^{225}$ Notably, no anti-Catholic sentiment was expressed by any of the delegates. Nor was there any expression of a desire to promote a pan-Protestantism.

${ }^{226} 2$ DEBATES OF $1850-51$, supra note 3 , at 663. 
When this provision was put before the assembly, Delegate Larwill rose to propose to strike out the term "shall" and insert the word "may," following "General Assembly," to give the General Assembly the discretion rather than a mandate to create a common school system. ${ }^{227}$ This amendment was rejected without debate. ${ }^{228}$ The idea of leaving the creation of the common school system entirely to the discretion of the General Assembly was unacceptable to the delegates. As Delegate McCormick later pointed out:

It has been said, that we ought to trust the management of this interest to the General Assembly. But now, for forty-eight years the General Assembly has been entrusted with this matter. Under the old Constitution it is provided that public schools and the cause of education shall be forever encouraged; and, under this constitutional provision, we have trusted the General Assembly for forty-eight years; and we may trust them for forty-eight years longer, without any good result. We have never yet had a law passed upon the subject which has not squandered the public school funds. Our acts of Assembly upon this subject have been either wasteful or impracticable - like the common school law of the session before last, which has proved utterly impracticable throughout the whole of the military district. Our system of common schools, instead of improving in legislative hands, has been degenerating; and I think it is time that we establish and carry out an efficient system of common school education or abandon the whole thing entirely to the virtue and intelligence of the people. ${ }^{229}$

The next focus of debate was the language requiring the General Assembly to "place the means of instruction in the common branches of education for a suitable portion of each year within the reach of all the children therein, of suitable age and capacity for learning." An amendment was proposed to change "suitable portion of each year" to a minimum school term of six months. ${ }^{230}$ Many delegates worried that a six-month minimum term requirement would be too difficult to implement immediately. At the time of the debates, some districts offered only three-month school terms. ${ }^{231}$ The concern was that the public sentiment in some of those districts might not support the immediate expansion of the school term. Further, Delegate Leadbetter, whose neighborhood supported a school for more than six months of the year, argued:

[T]aking the public money and the taxation together, they have never yet been sufficient to support the school in our neighborhood. It has always required the special contributions of those who send their children to school. This proposition ... cannot secure good schools. You may seek

\footnotetext{
${ }^{227} I d$. at 699.

${ }^{228} \mathrm{Id}$.

${ }^{229} \mathrm{Id}$. at 702 .

${ }^{230} I d$.

${ }^{231}$ Id. at 704 .
} 
to compel a school to be kept six months in every district, but in many cases, they will not be such schools as ought to be encouraged. I would far rather have a good school of three or four months continuance than a bad school of six months. ${ }^{232}$

Other delegates were concerned that if the General Assembly attempted to levy a tax sufficient to keep a six month minimum school term in every district, the "burdens and benefits must fall very inequitably on the different districts." 233 Delegate Hamilton elaborated:

[How can the school fund] be divided among the districts of the State, so as to enable every district to have school for six months? Perhaps gentlemen will say, that it should be divided among the districts in proportion to the number of children in each district. How will this work? It is frequently the case that one district has as many as seventy-five children, while one adjoining has but twenty-five - and yet the children in the latter may be so situated, that they must have a district where they are, or else have no school. Now, if you divide the money according to this rule, you must give to the first, three times the amount you give to the latter. And the amount drawn by the first, may be an amount amply sufficient to keep six months - nay, even nine months school—and have a good teacher, too; and I take occasion here to say, that the most important part of the school system, is to have good teachers - indeed, without them, no system is worth much - while the latter will draw so little, that it must contribute private means, or else have six months of inferior or worthless school. ${ }^{234}$

Delegate Hamilton went on to point out that the taxpayers would not support a levy that did not return equal per-pupil funding to each district.

Again it is suggested, that the General Assembly should levy a sufficient sum, and so divide it as to employ a competent teacher in every district. They say, that twenty-five children need as good a teacher as seventy-five, and they should have one. ... Our people submit cheerfully to taxation for purposes of education, but they want, and they will have, the benefits of taxes levied for those purposes divided among the people equally-in other words, among the school districts in proportion to the number of children in each district. This rule does not always return as much tax to some districts as they paid [.] ${ }^{235}$

Delegate Hamilton believed that, if a six-month minimum term were mandated, the difficulties in distributing tax money throughout the districts would result in low quality schools in some districts. He concluded:

\footnotetext{
${ }^{232} I d$. at 702 .

${ }^{233} I d$. at 701 .

${ }^{234} I d$.

${ }^{235} I d$.
} 
The only thing [the General Assembly] could do would be to levy an aggregate amount on the township, to be divided among the districts, and while one might get 100 dollars another might get but one third that sum. So that while the first can keep a school without difficulty — and we will suppose a good one too- the last must have an inferior one, or raise the deficit by private contributions. So that in the end the proposition to require every district to keep six months school is a proposition to increase the quantity and nothing else. ... [U]ntil our state is more densely and equally populated they cannot all have it. ${ }^{236}$

Another delegate responded that the problem of how to distribute tax dollars for schooling would be surmountable in the context of an organized, statewide system. An efficient statewide system of schools would have fewer school districts; equitable distribution of taxes among them would be more easily accomplished than under the existing state law. According to Delegate McCormick:

[The] proposition [is] not any more impracticable than our present system of districting and distributing the school fund of the state. ... [I]f we have the number of children - if we know how much it will require to keep a school in each district of the state for three months in the year, we may easily make a just estimate for six months. One of the arguments made use of here, is, that the taxes will be too high, on account of the number of school districts. ... [O]ne of the objects to be attained by the amendment ...will be, to increase the size, and thereby reduce the number of the districts. $^{237}$

Other delegates objected to the six-months school provision on the grounds that it was too short. Delegate Hootman suggested a nine-months school provision. ${ }^{238}$ Delegate Manon responded that he would be in favor of schooling fourteen months a year; and he believed "some of the Yankee school teachers could put in that amount of time without much difficulty." 239

Ultimately, both the nine-months and the six-months school term proposals failed. Following the extended debate on the proposals for a six-month minimum school term, an amendment proposed by Delegate Gregg to strike the words "and place the means of instruction in the common branches of education for a suitable portion of each year, within the reach of all children therein, of suitable age and capacity for learning" was passed without discussion. ${ }^{240}$ Thus, no constitutional mandate emerged on the length of the school term or the precise formula for distributing tax dollars for schooling. The length of the term and the manner of distributing the taxes - but not the essential matter of the creation of a thorough and efficient system of common schools-would be left to the discretion of the General Assembly.

$$
\begin{aligned}
& { }^{236} I d \text {. } \\
& { }^{237} I d \text {. at } 702 . \\
& { }^{238} I d \text {. at } 699 . \\
& { }^{239} I d \text {. } \\
& { }^{240} I d \text {. at } 704 .
\end{aligned}
$$


The delegates also decided to leave two other important matters to the discretion of the General Assembly: the creation of a State Superintendent of Common Schools and the establishment of professional teacher training programs. The advantages of having a State Superintendent were argued by many of the delegates, perhaps most succinctly by Delegate Stidger:

The advantages to be derived from the services of such an officer, it seems to me, would naturally occur to every mind, by the efficiency and uniformity which he would be able to impart to the workings of the whole system. The want of uniformity has been a matter of serious complainthas added largely to the expensiveness of the system, and given cause for most of the objections to its adoption by the people at large. And this certainly would be obviated by means of a State Superintendent and his associates. I have no doubt that the reduction of the expenses of the system which would result from uniformity in its operations, would advance the interests of the school fund, and increase it in amount annually far beyond the salaries of superintendents. Such was the case I believe when this plan was tried in 1836-7. We had then a most efficient officer in the capacity of State Superintendent, [Mr. Samuel Lewis]. ${ }^{241}$

The opponents to a constitutional mandate for a State Superintendent, however, argued against the expense of a State Superintendent and assistant superintendents for each county. ${ }^{242}$

Delegate Hitchcock pointed out that the creation of such an office was obviously within the competency of the General Assembly, as it had created such an office before, and that if the people wanted it they could have it. ${ }^{243}$ He argued further:

So zealously has this matter been pressed upon the public attention, that if the people had desired it, they certainly would [have] created the office. But now the convention is called upon to create this office ... when there is no law to control them, and define their duties. It seems to me ... that we had better leave the whole subject to the General Assembly. ${ }^{244}$

Ultimately, the provision for a State Superintendent of Common Schools was scrapped.

The rejection of the language providing a constitutional mandate for the creation of the office of State Superintendent of Common Schools was undoubtedly perceived as a defeat for the friends of education who had campaigned for the creation of a

${ }^{241}$ Id. at 707. Samuel Lewis served as Superintendent of Common Schools in 1836 on a salary of $\$ 500$. His salary was increased to $\$ 1,200$ by 1838 . During his superintendence, Lewis is said to have saved the state more than $\$ 60,000$ through investigations of the management of school lands. EDUCATION IN OHIO, supra note 85, at 335.

${ }^{242} 2$ DeBATES OF $1850-51$, supra note 3 , at 706. See id. (remarks of Delegate Woodbury) (arguing that giving assistant superintendents control over the business of the common schools could lead to collusion with booksellers and other corrupt acts).

${ }^{243}$ Id. at 707 .

${ }^{244} I d$. 
State Superintendent since 1836. ${ }^{245}$ All of the members of the Standing Committee on Education voted in favor of a constitutionally mandated State Superintendent, but were outvoted by a tally of fifty-nine to twenty-seven. ${ }^{246}$ This defeat, along with the defeat of the provision calling for state-supported professional teacher training, were major disappointments to the friends of education. ${ }^{247}$ At the close of the debates on all of the educational provisions, Delegate Curry argued that without these provisions, the operation of the constitutional provisions would be "entirely inefficacious, and its result useless - that it will in fact be, to the people of the State, no better than so much blank paper."248 He urged the delegates to defeat the amended provisions; and, indeed, four of the seven members of the Standing Committee on Education - including its chair — voted against the final version. ${ }^{249}$

The final versions of the educational provisions adopted by the 1850-51 Convention for the Revision of the Constitution of the State of Ohio, ratified by the people of Ohio, did not give the friends of education everything they had hoped for. In requiring the General Assembly to secure a "thorough and efficient system of common schools," however, the convention had provided a constitutional mandate for the creation of a school system that would embody the common school ideal.

${ }^{245}$ See supra notes 101-20 and accompanying text. A provision requiring a State Superintendent of Schools was, however, added to the Constitution by amendment in 1912 . See infra notes 312-13 and accompanying text.

${ }^{246} 2$ DEBATES OF 1850-51, supra note 3, at 707.

${ }^{247}$ The second and fourth provisions of the second report (see supra note 211) were stricken without any recorded debate. 2 DEBATES OF 1850-51, supra note 3, at 704-05.

${ }^{248} I d$. at 711 .

${ }^{249} I d$. The final vote for the pared-down provisions was 54 in favor and 37 against. Id. The members of the Committee who voted against the final version were the Chair, Harmon Stidger, Otway Curry, Samuel Quigley, and John Smith. The language of the provisions that were ratified by the voters is as follows:

Section 1:

The principal of all funds, arising from the sale, or other disposition of lands, or other property, granted or entrusted to this State for educational and religious purposes, shall forever be preserved inviolate, and undiminished; and the income arising therefrom shall be faithfully applied to the specific objects of the original grants or appropriations.

Section 2:

The general assembly shall make such provisions, by taxation, or otherwise, as, with the income arising from the school trust fund, will secure a thorough and efficient system of common schools throughout the State; but no religious or other sect, or sects, shall ever have any exclusive right to, or control of, any part of the school funds of this state.

OHIO CONST. of 1851, art. VI, $\S \S 1-2$. 


\section{ImPlementing, Challenging, AND Honing the Vision OF THE CONSTITUTIONALLY MANDATED COMMON SCHOOLS}

\section{A. The Law of 1853: Reorganization, Supervision, and Maintenance of the Common Schools}

The new Constitution was the first stop on a long journey from localized, ad hoc educational arrangements to a system of free, universal schooling. Following their success in the constitutional convention, education activists continued spreading the gospel of good schools in teaching institutes, journals, meetings, and public addresses. $^{250}$ They also increased their efforts in the legislature. ${ }^{251}$ There was rejoicing in the Ohio State Teachers' Association when the General Assembly enacted the Law of 1853 "[t]o provide for the reorganization, supervision, and maintenance of Common Schools." 252

The Law of 1853 provided the practical fundamentals for a statewide system under public control. It included provision for a central authority, a method for distributing funds, and public oversight of operations. It created the office of Commissioner of Common Schools and replaced the township system of taxation and control with a countywide system. ${ }^{253}$ Each township became a district under the control of a board of education, with the many previously existing "districts" becoming sub-districts. Supervision of the schools was transferred from corporate

\footnotetext{
${ }^{250}$ In 1851, Asa D. Lord, M.D., a founding committee member of the Ohio State Teachers' Association, published a magazine "devoted to the promotion of popular education." In the opening statement of its first volume, Dr. Lord expressed the value of a good common school education and an "efficient system of public schools." Public schools, he said, benefit all parents, rich and poor, by providing an education equivalent to private schools to all children. They benefit all taxpayers because money is spent on the young people living in their community to make them intelligent and industrious, and to give them good habits and a sense of morality. All property owners are benefited because property values drop where surrounded by neglected children allowed to become a "generation of idlers, thieves and gamblers, who will prey upon his property and that of every other honest, industrious and frugal citizen." To emphasize his last point, he asks: "What was real estate worth in Sodom?" Asa D. Lord, Introduction, in 1 Public School Advocate, and High School Magazine (Asa D. Lord ed., 1851).

${ }^{251}$ EDUCATION IN OHIO, supra note 85, at 384-85.

${ }^{252}$ An Act to Provide for the Reorganization, Supervision, and Maintenance of Common Schools, 1853 Ohio Laws 429 (Mar. 14, 1853) [hereinafter Common Schools Act]. See EDUCATION IN THE STATES, supra note 74, at 953.

${ }^{253}$ Common Schools Act $\S 47,1853$ Ohio Laws at 446 (creating the office of State Commissioner); id. $\S 37,1853$ Ohio Laws at 443 (providing for the apportionment of funds among counties); id. $\S 44,1853$ Ohio Laws at 445 (providing for the appointment of a county board of school examiners); id. $\S 63,1853$ Ohio Laws at 449-50 (requiring an annual levy at the county level for the support of common schools). See EdUCATION In THE STATES, supra note 74, at 953-54. But see MiLler, supra note 24, at 33 (stating that prior to 1850, a guaranteed state school fund was created and laws were passed to allow various officials to levy taxes to make up for deficiencies in this fund).
} 
authorities to elected boards of education. ${ }^{254}$ Each board of education was empowered under the act to prescribe any rules, and to take any steps, reasonably necessary to promote the education and morals of the children attending its schools. ${ }^{255}$ The right to vote in school elections was no longer limited to householders and "resident taxpayers," but was extended to all those who were qualified to vote in state and county elections. ${ }^{256}$ The law also ordered tuition funds to be distributed on an "equitable" versus "equal" basis. ${ }^{257}$

In spite of the provisions of the 1853 law, the transformation to a statewide system of schools did not happen overnight. ${ }^{258}$ Localism persisted and the transition to a graded system of common schools was gradual. Moreover, some of the issues that had arisen during the constitutional debates continued to be controversial. Providing a non-sectarian education, in particular, proved to be more problematic than Calvin Stowe or the constitutional delegates had anticipated. ${ }^{259}$ In Cincinnati, for example, Jewish and Catholic parents objected to the use of the King James Bible in the schools. ${ }^{260}$ However, when the Cincinnati Board of Education decided to remove all religious books, including the Bible, from the curriculum, it was Protestants who objected. ${ }^{261}$

\section{B. Continuing Controversies: Religion, Money, and Control}

\section{Cincinnati v. Minor: The Ohio Constitution Does not Require the Bible Be Used in Schools}

A group of Christian taxpayers brought suit to stop the Cincinnati Board of Education from removing the Bible from its curriculum. They argued that the Bill of

\footnotetext{
${ }^{254}$ Common Schools Act $\S \S 1-17,1853$ Ohio Laws at 429-35; id. $\S 11,1853$ Ohio Laws at 433 (boards of education "shall be and hereby are invested in their corporate capacity with the title, care and custody of all school houses, school house sites, school libraries, apparatus or other property belonging to the school districts as now organized").

${ }^{255} I d$. $\S \S 11,13,1853$ Ohio Laws at 433-34. See id. $\S 16,1853$ Ohio Laws at 435 (providing that " $[\mathrm{w}]$ henever it shall happen that persons are so situated as to be better accommodated at the school of an adjoining township, or whenever it may be desirable to establish a school composed of parts of two or more townships, it shall be the duty of the respective boards of the townships in which such persons reside, or in which such schools may be situated, ... to transfer such persons for educational purposes to the township in which such school house is or may be located").

${ }^{256} I d$. $§ 2,1853$ Ohio Laws at 429-30.

${ }^{257}$ See BuRNS, supra note 53, at 70 . The distribution of tax dollars among the various districts had been a matter of great concern during the constitutional debates. See supra notes 232-40 and accompanying text.

${ }^{258}$ For example, it was not until 1861 that state authority really became apparent. In 1861 , an act was passed forcing local school authorities to account to the State Commissioner of Common Schools for funds received. See EduCATION In THE STATES, supra note 74, at 954.

${ }^{259}$ See supra notes $138-42$ and accompanying text.

${ }^{260}$ Board of Education of Cincinnati v. Minor, 23 Ohio St. 211, 213-14 (1872).

${ }^{261} I d$. at 211 .
} 
Rights of the Ohio Constitution mandated religious instruction in schools. ${ }^{262}$ They also argued that convention delegates, in creating the Constitution of 1851, considered and rejected the provision that would have taken religious instruction out of the schools, "nor shall the rights of conscience be in any case interfered with.",263

The Supreme Court of Ohio, in a unanimous opinion, determined it had no power to require religious instruction in the schools, absent legislative provision. ${ }^{264}$ Justice Welsh opined that the state has no right to tax people to support worship and therefore no right to tax people to support religious instruction:

Religion, morality, and knowledge are essential to government, in the sense that they have the instrumentalities for producing and perfecting a good form of government. On the other hand, no government is at all adapted for producing, perfecting, or propagating a good religion. ... [And] if we have no right to tax him to support "worship," we have no right to tax him to support religious instructions; religion... can best be secured by adopting the doctrine of this seventh section in our own bill of rights... [the] doctrine of "hands off." Let the state not only keep its own hands off, but let it also see to it that religious sects keep their hands off each other. At last solved [is] the terrible enigma of "church and state"...nowhere more fairly and beautifully set forth than in our own constitution. $^{265}$

Republican doctrine, he went on to explain, requires total inactivity by the state in divine matters, for the protection of the religious minority:

It means a free conflict of opinions as to things divine; and it means masterly inactivity on the part of the state, except for the purpose of keeping the conflict free, and preventing the violation of private rights or of the public peace. Meantime, the state will impartially aid all parties in their struggles after religious truth, by providing means for the increase of general knowledge, which is the handmaid of good government, as well as of true religion and morality. The "protection" guarantied by the section in question, means protection to the minority. The majority can protect itself. Constitutions are enacted for the very purpose of protecting the weak against the strong; the few against the many....We are all subject to prejudices, deeper and more fixed on the subject of religion than on any other. Each is, of course, unaware of his own prejudices. Were Christians in the minority here, I apprehend no such a policy would be sought by them. The true doctrine on the subject is the doctrine of peaceful

\footnotetext{
${ }^{263}$ Minor, 23 Ohio St. at 229.

${ }^{264} I d$. at 211 (syllabus $\uparrow \uparrow 1-2$ ).

${ }^{265} I d$. at $248-49$.
}

${ }^{262}$ OHIO. CONST. art I, $\S 7$ states, in part:

Religion, morality, and knowledge, however, being essential to good government, it shall be the duty of the General Assembly to pass suitable laws, to protect every religious denomination in the peaceable enjoyment of its own mode of public worship, and to encourage schools and the means of instruction. 
disagreement. The great bulk of human affairs and human interests is left by any free government to individual enterprise and individual action. Religion is eminently one of these interests, lying outside the true and legitimate province of government. The only fair and impartial method, where serious objection is made, is to let each sect give its own instruction, elsewhere than in the state schools, where of necessity all are to meet. ${ }^{266}$

Finally, he quoted James Madison:

"Religion is not within the purview of human government." And "Religion is essentially distinct from human government, and exempt from its cognizance. A connection between them is injurious to both. There are causes in the human breast which insure the perpetuity of religion without the aid of law." 267

The controversy created by the Cincinnati Board of Education did not quickly die away. Issues relating to the separation of church and state were vigorously debated in throughout the $1870 \mathrm{~s}^{268}$ In 1874 the question of religious instruction in statesupported common schools was debated again by the members of Ohio's Third Constitutional Convention. ${ }^{269}$

\section{The Third Constitutional Convention (1874)}

During the Third Constitutional Convention, a motion was made to strike the words, "but, no religious or other sect, or sects, shall ever have any exclusive right to, or control of, any part of the school funds of this state" from Section 2 of the education provisions. ${ }^{270}$ The motion to strike was rejected following a debate which revealed much about the thinking of the Ohio constitutional framers on the issue of religious instruction in publicly-supported schools. The crux of the debate centered on whether any part of the school funds should be diverted to parochial schools. The answer was a vehement "no."

\footnotetext{
${ }^{266} I d$. at 251 .

${ }^{267} I d$. at 254 .
}

${ }^{268}$ Those who favored strict separation of church and state had proposed an amendment to the U.S. Constitution that would forbid tax support to any school or institution "under the control of any religious or anti-religious sect, organization, or denomination, or wherein the particular creed or tenets of any religious or anti-religious sect, organization, or denomination shall be taught." H.R.J. Res. 1, 44th Cong., 4 ConG. REC. 5453 (Aug. 11, 1876). Another group organized a national movement seeking an amendment to the U.S. Constitution that would make the United States a "Christian nation" and would allow for non-sectarian Christian teaching in schools. See generally ProceEdings of the Convention to SECURE A RELigious AMENDMENT to the CONSTITUTION (1873).

${ }^{269}$ No major revisions to the existing educational sections were adopted by the Convention. Further, the changes to other sections that were adopted by the 1874 Constitutional Convention were not ratified by the people of Ohio and did not become law.

${ }^{270} 2$ Official Report of the Proceedings and Debates of the Third Constitutional CONVENTION OF OHIO 2221 (1874) [hereinafter DeBATES OF 1874]. 
The proposal to strike the constitutional language that blocked the diversion of funds to religious schools- - "but, no religious or other sect, or sects, shall ever have any exclusive right to, or control of, any part of the school funds of this state"failed by a sweeping margin. In fact, only the delegate proposing the amendment voted in its favor. ${ }^{271}$ Nevertheless, the debate was intense, as the convention took place during the height of tensions between Catholics and Protestants over public school funding around the country. ${ }^{272}$

Delegate Asher Cook believed that diverting the public school system funds to sectarian institutions "would destroy its [efficiency] and keep the different sects and denominations in perpetual strife over its division." 273 For him, the dangers of sectarianism were real. He argued:

It is little creditable to mankind that differences in religious opinions have engendered the most cruel enmity between them, and the world has witnessed no blacker crimes than those perpetrated in the name of religion; and what makes it incomparably worse, and more to be dreaded than other crimes, is the fact that the perpetrators, under the insane fervor of religious excitement, believe they can in no way worship God so acceptably as by baptizing the earth in what their frenzied zeal calls infidel blood. ${ }^{274}$

The cure for the problems of sectarianism, he felt, could be found in the common school, where diverse groups of people could be united. He stated:

Here the children of a district, and often those of an entire village, are united in one school, where all cause of strife and contention is removed, and their minds, true to the instincts with which they are endued, rich and

\footnotetext{
${ }^{271} I d$. at 2221.

${ }^{272}$ Anson Phelps Stokes \& Leo Pfeffer, Church and State in the United States 433 (2d ed. 1964)(President Ulysses S. Grant, in 1875, addressing Army of the Tennessee) (emphasis added):

Encourage free schools, and resolve that not one dollar appropriate for their support shall be appropriated for the support of any sectarian schools. Resolve that neither the State nor nation, nor both combined, shall support institutions of learning other than those sufficient to afford every child growing up in the land the opportunity of a good common school education, unmixed with sectarian, pagan, or atheistical dogmas. Leave the matter of religion to the family, altar, the church, and the private school supported entirely by private contributions. Keep the church and state forever separate.

Shortly thereafter, the Forty-fourth Congress came within a breath of adopting the Blaine amendment, which nearly changed the First Amendment to the United States Constitution to read: "No State shall make any laws respecting an establishment of religion or prohibiting the free exercise thereof; and no money raised by taxation in any State for the support of public schools, or derived from any public fund therefor, nor any public lands devoted thereto, shall ever be under the control of any religious sect..." Id. at 434. See H.R. Res. 1, 44th Cong., 4 CONG. REC. 205 (Dec. 14, 1875) (statement of Rep. Blaine) (introducing the resolution).

${ }^{273} 2$ DEBATES OF 1874 , supra note 270 , at 2188.

${ }^{274} I d$.
} 
poor, mingle together, for a loving group of little friends, who, hand in hand, march bravely up the rugged hill of science, making the ascent easy by each other's aid, and smoothing its rugged surface by glad peals of laughter, which ring out merrily and clear over hill top, across valley and up the mountain side, until their echoes wake up a joyous community to thank God for the common schools.

The lone delegate in favor of funneling part of the school funds to parochial schools felt it was unfair to force Catholic parents, who could not in good conscience send their children to the common schools, to pay a double tax. ${ }^{275}$ The prevailing Catholic view was that reading the Bible to children without note or comment was abandoning them to "dangerous speculation." schools of the Protestant Bible. Catholic school supporters feared that a lack of "religious atmosphere" would leave their children to "be left to perish in the dreary and soul-destroying wastes of deism." 277 According to Delegate Carbery, Catholic persons were being forced to pay tax for a public school system not available to them, as well as the tuition expenses of their own schools. ${ }^{278} \mathrm{He}$ exclaimed, "the Catholics of the state are subject to a legalized robbery every year."279

The Catholic school activists desired an apportionment of funds on a pro rata basis. $^{280}$ Delegate Carbery advocated a system of schools with greater parental choice and community management, rather than a "huge omnibus system, which first swallows everything in the State, to become lost in its turn in a gigantic National Bureau, with its machinery concentrated in Washington, and which would eventually obliterate every feature of individuality from the children of the people." ${ }^{281}$ Carbery read into the record an excerpt from Catholic World, which purported to represent the view of the Catholic minority on the Bill of Rights. It stated:

The plain reading of the Bill of Rights, and its right meaning in Catholic minds, is ... to encourage such schools as may be established by the spontaneous action of the people, or any division of the people, and to sustain the same in exact proportion to the number of children under

${ }^{275} I d$. at 2196-2206. This misconceived argument is still heard today from parents who send their children to private school. See Molly Townes O'Brien, Questioning the Power of Consumerism to Reform Public Education, 75 ST. JOHN's L. REV. 233, 249 (2001)(all taxpayers - not only those who have children - pay for the benefit of living in a society that educates all of its children).

${ }^{276} 2$ DeBATES OF 1874 , supra note 270 , at 2204. Many of the common school crusaders, like Stowe, believed that religious education could avoid offending the consciences of believers from different sects by assigning children to read the scriptures without commentary. See Board of Education of Cincinnati v. Minor, 23 Ohio St. 211, 212 (1872).

${ }^{277} 2$ DEBATES OF 1874, supra note 270, at 2203.

${ }^{278} I d$. at 2195.

${ }^{279}$ Id. at 2196.

${ }^{280} I d$. at 2206.

${ }^{281} I d$. (stating also "the nearer the management is to the parents, and to a distinct community, the better in the long run for the child and for the State"). 
instruction. This would be a use of the public money which would violate no man's conscience, and would be found to act as a panacea for many social troubles. ${ }^{282}$

The response to this proposition was an emphatic refusal to divert monies from the public school system. ${ }^{283}$ According to Delegate Pease:

[T] he moment we abandon our common schools, the moment we begin to cut down and lessen the effect of this general education, that moment we submit ourselves to become a prey to these theories and "isms," and schisms, and divisions, and the anarchy resulting therefrom. ${ }^{284}$

Delegate Voris then rose to emphasize the importance of supporting one common school system rather than a variety of sectarian schools. He asked the convention: "Divide the public moneys among the different religious bodies of the State, or leave the education of our children to the caprice of each parent, or to the dictation of the churches, and where would we land? Where would be the unity of the people?"285 His answer to this question was that dividing public money amongst religious groups would violate the separation of church and state:

The policy of the State has never gone further than to give equal liberty and protection to all religious denominations. The State cannot give denominational support to the schools of its various religious bodies. It is utterly impracticable to do it, and to give to some and not the others would be unjust and partial. To give this support at all would be antagonistic to the genius of our institutions, and subversive of the true principles of government. Our theory of government is established upon the idea of entire separation of Church and State. ${ }^{286}$

Delegate Voris concluded that public education, the greatest contribution to American liberties, must be handled with extreme care:

It is our duty and privilege to perfect and jealously guard our public school system. These schools furnish the people with their great means of equalizing element that unifies the youth of our country and makes our people homogeneous. The future hopes of our country are centered in them, for all its hopes depend on the intelligence and virtue of the young.

${ }^{282}$ Id. at 2206 (quoting The Catholic View of Public Education in the United States, 3 CATH. WORLD 686 (1868-69)).

${ }^{283} 2$ DEBATES OF 1874, supra note 270, at 2207 (remarks of Delegate McCormick) (“"[T]he great majority of our citizens are utterly opposed to any change in our public school system.... It is to the honor of the state, that under our present system she seeks to oppress none, but grants equal privilege to all without distinction of race, color or sect, and those who do not accept that privilege, do so from choice, and not compulsion.").

${ }^{284} I d$. at 2215 (reflecting upon both the diversion of funds to religious institutions and the limiting of funds to the "necessary" branches).

${ }^{285} \mathrm{Id}$. at 2233 .

${ }^{286} I d$. 
These schools are the offspring of a free people's grandest contribution to liberty; and so long as we keep them in healthful vigor, our people will be free-free in politics, free in intelligence, free in faith, and triumphant in all the elements of human greatness. ${ }^{27}$

The debate over support for religious educational institutions concluded on the following note by Delegate Miner: "protection to all, equally, but support to none."288

By 1874 , no one doubted the need for a system of education to maintain a republican form of government. ${ }^{289}$ The common school system was seen to be necessary for the preservation of unity, for the self-protection of the republic, and to promote the democratic principles of equal opportunity. ${ }^{290}$ As Delegate Horton put it, "if we would have the people govern themselves ... they must learn to think. It is utterly idle to talk of maintaining a form of government like ours unless the people, into whose hands that government is entrusted, first, become so educated that they can understand its principles, its provisions, and its rules."291

In contrast to the earlier constitutional debates, there was no argument that parents, rather than the state, should bear the cost of education. Instead, there was now general agreement that the state ought to bear the burden of providing for popular education because the benefits of education accrued to the state. According to Asher Cook, Chairman of the Committee on Education, "Public education includes instruction in all things necessary to fit the individual for a proper discharge of his, or her duties as a member of society, and which directly tend to the advancement of the state. ${ }^{292}$

Moreover, the delegates assumed that it was far more economical for the state to educate the impoverished than to leave them to be educated on the streets and in prisons. ${ }^{293}$ Delegate Miner summed up the prevailing view on education when he said:

It is in harmony with the true spirit of democratic republic to require every citizen to qualify himself for the right of suffrage and for earning an

${ }^{287} I d$. at 2236.

${ }^{288} I d$. at 2254.

${ }^{289} I d$. at 2187 (remarks of Asher Cook, Chairman of the Committee on Education) ("We must educate or the Republic will perish. A Republican form of government cannot be maintained without the education of the people.").

${ }^{290} I d$. at $2217-18$ (remarks of Delegate Peas) (“[T]he children of the poorest man in Ohio, or those of the loneliest widow in the State, shall have as good an opportunity for a good and thorough education, in the common schools of the State, as the rich man's children.").

${ }^{291} I d$. at 2224.

${ }^{292} I d$. at 2187.

${ }^{293} I d$. (remarks of Chairman Asher Cook) ("[E]ducation must be given in the school, or in the prisons."); $i d$. at 2245-46 (remarks of Delegate Miner) ("It is in harmony with the true spirit of democratic republic to require every citizen to qualify himself for the right of suffrage and for earning an independent living. Tax-payers, who furnish the money to educate all the people, have the right to require that all shall be educated, in order that crime and pauperism, and the public burdens caused by them, may be reduced to a minimum."). 
independent living. Tax-payers, who furnish the money to educate all the people, have the right to require that all shall be educated, in order that crime and pauperism, and the public burdens caused by them, may be reduced to a minimum, and the ballot wielded only by intelligent voters. ${ }^{294}$

Some, however, did question the need and expense of educating in the "fancy branches" and proposed to limit the growth of the system of common schools. ${ }^{295}$ By then, however, Ohioans were quite proud of their schools and unwilling to put a check on their prosperity. ${ }^{296}$ The response of delegates to the idea of limiting the expansion of common schools was that education and its expenses were all part of living in a civilized society:

If men desire to get along without spending money, if the spending of money is something that must be avoided at all hazards, it can be done by going and living where money is not required.... [I]f we are to enjoy the benefits of civilization, if we are to enjoy education, if we are to live on with the cultivated tastes and desires that civilization brings, we must prepare ourselves to spend the necessary amount of money, because they cannot be obtained without money and without price."297

Ultimately, the proposal to limit the growth of the common schools failed and the common school system continued to expand. ${ }^{298}$

${ }^{294}$ Id. at 2254

${ }^{295}$ Id. at 2186. A majority of the Committee on Education proposed to add the following clause to Section 2: "The power of taxation, conferred by this section, shall be limited to a sum sufficient to educate all the children of the State, in such common and necessary branches of learning as shall be prescribed by law." This would have excluded education in the "fancy branches" such as trigonometry, surveying, chemistry, geology, astronomy, philosophy, rhetoric, logic, Greek, and French. Id.

${ }^{296}$ Id. at 2187 (remarks of Asher Cook, Chairman of the Committee on Education) ("These schools are the State's brightest jewels and her patriotic tax-payers will never allow that crown to be torn from her brow, or tarnished, under a false plea for economy.").

${ }^{297} I d$. at 2226.

${ }^{298}$ Delegate Horton observed:

[T] he people of Ohio have not been contented with the common school system which they established in the first settlement of our state. As they have grown rich ..., as they have cleared away the forests and built themselves homes, they have felt the necessity of a higher order of education. And this, not by any artificial means, but by a natural growth and a natural combination of circumstances, have grown up the high schools of our state, where our children acquire not merely the common and ordinary branches of education as they were known in those early times. We want a more liberal, a more enlightened, and a more extended culture. I know ... that in the town where I live, the children of the poor, the children of the laboring men, the children of women who work themselves, are foremost in the high school, and that the scholars who stand first there are those who would find it impossible to obtain anything like an approach to a liberal education without these opportunities; and I know ... that there is no portion of the tax which the people of my county are called upon to pay, which they pay more cheerfully than that which they pay for the support of their high school. I know that with them the high school has grown to be looked upon as a part of our 


\section{The Constitutional Convention of 1912 Centralizes Authority}

By 1874 , the ideal of the common school was well established in the law and in the public psyche. The reality of the common school remained more problematic. In 1872, Thomas W. Harvey, the Commissioner of Common Schools, complained in his report to the General Assembly and the Governor that many schools could not afford to hire qualified teachers and that children in these schools showed no real enthusiasm for their schoolwork. ${ }^{299}$ He stated:

Something must be done soon by way of redistricting the townships, or for providing for centralization of the schools in Ohio. Our townships have from six to nine sub-districts in many instances, and very many of these schools are run during the summer months with from 3 to 8 scholars. The winter schools also are proportionately small. ${ }^{300}$

That same year, Ashtabula County began transporting children from the townships to central village schools. ${ }^{301}$ And in 1898 , legislation was passed allowing townships to alter the boundaries of subdistricts and to provide inter-district transportation. Even so, the progress toward consolidation and centralization was minimal. ${ }^{302}$ In 1910, approximately two thirds of all students were enrolled in public schools with very little supervision by, or influence from, the state. Inequities in funding, discrepancies in the standards of education, and the lack of uniformity in curriculum all rekindled the movement for centralization that had been begun by the friends of education in 1836.

During the Constitutional Convention of 1912, a constitutional provision for centralized authority over the system - which the friends of education had sought for so many years - was finally adopted. The new constitutional language declared: "Provision shall be made by law for the organization, administration and control of the public school system of the state supported by public funds. ${ }^{" 303}$ This first line of Article VI, Section 3, was proposed and adopted "so that there can be no question about the control of the school systems as well as the handling of the school funds." ${ }^{\text {"304 }}$ It was also to "establish definitely that the state shall for all time, until the constitution is further amended, have complete control over the educational system,

common school system - almost part of their domestic life, and something which they

cling to and would not give up.

Id. at 2286,2225 .

${ }^{299}$ EdUCATION IN THE STATES, supra note 74, at 957.

${ }^{300} I d$.

${ }^{301} I d$. at 958 .

${ }^{302}$ Id. at $957-58$.

${ }^{303}$ Ohio Const. art. VI, § 3. See R.M. Eyman, History of County School Districts in OHIO 1 (1962).

${ }^{304} 2$ Proceedings and Debates of the Constitutional Convention of the State of OHIO 1504 (1913) (provisions for home rule were adopted from this constitutional convention and Delegate Knight sought to make clear that home rule did not apply in the public school arena) [hereinafter DEBATES OF 1912]. 
and that no city, village or part of the state can withdraw itself, under the guise of a charter, from the public educational system of the state." ${ }^{305}$

The delegates did "not contemplate taking out of the hands of the local authorities the control and administration of their local schools, but gave to the state, beyond any question, the right to fix the standard and the right to organize an entire system, leaving to each local community the determination of the schools in the system." "306 The vision was "one complete educational system for the schools and all educational institutions supported by public taxation." ${ }^{\text {307 }}$

The following definitions were clarified by the members of the Standing Committee on Education: "District," in the context of this provision, had been considered with the township as a unit, but, concededly, was to be left to the state legislature to determine, wherein they might even "define the county as a unit",308 and "organization" did not mean management. ${ }^{309}$ The concept of a public school system was one of a system run entirely under the authority of the state, apart from higher educational institutions and completely separate from parochial schools. ${ }^{310}$ According to Delegate Knight, the public school system did not include parochial schools because "[t]here [was] no intention to put anything ... not supported by taxation under this system.",311

${ }^{305} I d$. at 1499.

${ }^{306} I d$.

${ }^{307} I d$.

${ }^{308} I d$. at $1500-02$.

${ }^{309} \mathrm{Id}$. at 1502.

${ }^{310} I d$. at 1916. "Public School System" was also distinguished from "educational system." The original proposal for section 3 included the right to organize, administer, and control the "public school and educational system of the state." According to Delegate Knight, "Public educational system" meant:

educational system supported in whole or in part by general and local taxation. In a majority of the states, as in this state, the general organization has been in the hands, as it should be, of a central lawmaking body. Now the import of those two words, "and educational" is this: We are reaching out at the present time and developing a normal school for the training of teachers for our public schools. We are supporting and maintaining three colleges, Ohio State, Ohio University an Miami University. The intent of that phrase "and educational" is that whenever, or if ever, it seems wise to the lawmaking body of the state to try to make a unified public educational system from the kindergarten at the bottom to the highest educational institutions supported by taxation, this proposal gives undoubted authority to do that, and there is nothing intended beyond that, and the insertion of the word "public" before educational will remove any ambiguity and all doubt about the intent to cover parochial schools in any way.

Id. at 1916. However, the words "and educational" were not included in the final provision adopted by the convention and ratified by the people of Ohio. Many of the delegates thought the language entirely too broad and were opposed to the general assembly having control over the state universities. Implied in this distinction is the concept of a public school system apart from higher educational institutions and completely separate from parochial schools.

${ }^{311} I d$. at 1916. 
The final provisions, adopted by the Constitutional Convention of 1912 and ratified by the people, are as follows:

\section{SECTION 3:}

Provision shall be made by law for the organization, administration and control of the public school system of the state supported by public funds; provided, that each school district embraced wholly or in part within any city shall have the power by referendum vote to determine for itself the number of members and the organization of the district board of education, and provision shall be made by law for the exercise of this power by such school districts. ${ }^{312}$

\section{SECTION 4:}

A superintendent of public instruction to replace the state commissioner of common schools, shall be included as one of the officers of the executive department to be appointed by the governor, for the term of four years, with the powers and duties now exercised by the state commissioner of common schools until otherwise provided by law, and with such other powers as may be provided by law. ${ }^{313}$

The long-sought addition of provisions for efficient organization and for a central authority under a state superintendent were finally in place. The addition of this language to the Ohio Constitution completed the constitutional agenda of the common school movement.

\section{The Constitutional “COMmon School IdEAL” IN THE ConteXt OF CONTEMPORARY EDUCATIONAL DEBATES}

Although the constitutional agenda of the Ohio common school movement was completed with the 1912 amendments to the constitution, the practical agenda of the movement-providing universal, publicly-supported education-remained incomplete. In requiring the creation of a "thorough and efficient system of common schools," the delegates to the 1850-51 Convention on the Revision of the Ohio Constitution sent an enormous mandate to the legislature. They required not only a radical change from the diverse schooling arrangements that were deemed ineffective to a single "system," but also continuing vigilance and funding to maintain the thoroughness and efficiency of that system. Creating and maintaining a system of common schools capable of delivering a high-quality education to every

\footnotetext{
${ }^{312} \mathrm{OH}$. Const. art. VI, $\S 3$.

${ }^{313}$ OH. Const. art. VI, $\S 4$ (in effect from July 14, 1913 to November 3, 1953). In 1953, the language was amended to provide for a state board of education. The amended language is as follows:

There shall be a state board of education which shall be selected in such manner and for such terms as shall be provided by law. There shall be a superintendent of public instruction, who shall be appointed by the state board of education. The respective powers and duties of the board and of the superintendent shall be prescribed by law.
} 
child in the state has proven to be a tremendous job. ${ }^{314}$ Without constant effort, upkeep, oversight, and reform, the common schools cannot satisfy the educational needs of a complex, diverse democracy. Thus, the building of the common school system envisioned in the Ohio Constitution is a continuing duty. In this sense, the practical agenda of the common school movement will always be incomplete.

The constitutional requirement that the General Assembly "secure a thorough and efficient system of common schools" articulates a constitutional vision that has ongoing contemporary significance. These words - "thorough," "efficient" and "common"- are imbued with constitutional values that impose upon the legislature a meaningful and definitive standard and an ongoing duty that must be met. ${ }^{315}$

Most evidently, the language is important in school finance litigation. ${ }^{316}$ Based on the theory that everyone benefits from the education of each child, the whole community is responsible for the cost of the common school-not just the parents. The mandate for a thorough education of each child places a heavy burden on the state, and requires consistent public support through taxation. Moreover, to carry out its mission of educating citizens for equal participation in a democracy, the common school must be free and must provide equality of opportunity for all. ${ }^{317}$ An education

\footnotetext{
${ }^{314}$ Soon after the adoption of the 1912 constitutional provisions, Governor James M. Cox surveyed the conditions of the state's schools and determined that students in rural school districts had less supervision, and less qualified, trained, and experienced teachers; they were poorly provided with educational and social centers, sanitary equipment, and furnishings; their schools had inadequate and poor quality school grounds and buildings; and less attention was paid to their health and the cleanliness of their environment. EyMAN, supra note 303, at 4144. The problems identified in the survey have not been easily resolved. In 1995, evidence presented in a case challenging the constitutionality of Ohio's school financing provisions showed that many children in Ohio still attended schools in decaying and unsafe buildings, and that many schools lacked the basic materials for learning. DeRolph v. State, 78 Ohio St. 3d 193, 206-10, 677 N.E.2d 733, 743-46 (1997)(holding that the public school financing system fails to meet Ohio's constitutional requirement that the legislature provide for a "thorough and efficient system of common schools"). See also DeRolph v. State, 97 Ohio St. 3d 434, 780 N.E.2d 529 (2002)(holding that legislative efforts to cure the flaws of the financing scheme were insufficient to meet constitutional standards).

${ }^{315}$ In the context of school finance reform, the Ohio Supreme Court has said that the constitutional mandate for a "thorough and efficient" system of common schools "calls for the upbuilding of a system of schools throughout the state, and the attainment of efficiency and thoroughness in that system is thus expressly made a purpose, not local, not municipal, but state-wide. . . A thorough system could not mean one in which part or any number of the school districts of the state were starved for funds. An efficient system could not mean one in which part or any number of the school districts of the state lacked teachers, buildings, or equipment."' DeRolph, 78 Ohio St. 3d at 203-04, 677 N.E.2d at 741 (quoting Miller v. Korns, 107 Ohio St. 287, 297-98 140 N.E. 773, 776 (1923)).

${ }^{316}$ See generally DeRolph, 97 Ohio St. 3d 434, 780 N.E.2d 529 (2002). See also McCusic, supra note 9.

${ }^{317}$ In DeRolph, the Ohio Supreme Court stated that a thorough and efficient system of common schools need not provide "equal" opportunities to all. The court nevertheless rejected as unconstitutional a funding scheme that failed to provide an adequate opportunity to every child. 78 Ohio St. $3 d$ at 211-12, 677 N.E.2d at 746. In a later opinion in the same case, the court quoted James Taylor's comment made during the 1850-51 Constitutional Convention
} 
for equal citizenship must be provided regardless of the child's address or economic circumstances and "regardless of the special interests which may seek to skew the allocation of resources to meet their own exclusive ends." ${ }^{318}$ Meeting this burden has proven over time to be a task of Sisyphean proportions. Each year, a new group of children enters the public schools, and public support must, again, be won; ${ }^{319}$ and each year, taxes must be raised and distributed, and the "thorough and efficient" system must be administered in the context of perpetually changing circumstances and ongoing debate. If the common school ideal encompassed only the issue of school finance and funding, it would continue to be controversial; but it entails much more.

The common school language also has important meaning in the context of school choice reforms. ${ }^{320}$ Recent school reform initiatives have adopted the mechanisms of vouchers and charters to provide public funding for parental choice of schools. These programs are supported by a variety of rationales; they have a wide range of goals and differ widely in the details of their execution. ${ }^{321}$ Some of the stated goals include: (1) providing an exit ticket for a poor child from a failing public school; (2) providing a publicly-supported option for parents and children whose values do not mesh with the values taught in the public school system; and (3) injecting market competition into the school system. ${ }^{322}$ Virtually all of these programs, however, envision a proliferating variety of available schools, competition

that the "true policy of the statesman is to provide the means of education. . . to every child in the State, the offspring of the black man equally with that of the white man, the children of the poor equally with the rich." 97 Ohio St. $3 d$ at 436, 780 N.E.2d at 531 (quoting 2 DeBATES OF 1850-51, supra note 3, at 11).

${ }^{318}$ Alexander, supra note 190 , at 356.

${ }^{319}$ The difficulty of this task is complicated not only by the vagaries of taxing systems and financial considerations, but also by individual and business interests that compete with schooling for tax dollars. See, e.g., Molly Townes O'Brien, At the Intersection of Public Policy and Private Process: Court Ordered Mediation and the Remedial Process in School Funding Litigation, 18 OHIO ST. J. ON DisP. RESOL. 391, 430-31 n.217 (2003)(collecting a list of agencies, associations, and private organizations with a particular interest in the outcome of Ohio school finance litigation). Public support for public schooling is also vulnerable because "we do not view other people's children as ours in many important ways." Martha Minow, What Ever Happened to Children's Rights?, 80 MinN. L. REV. 267, 295 (1995).

${ }^{320}$ The term "school choice" has been used to refer to any of a variety of school reform proposals, including private school tuition vouchers, charter schools, inter-district transfer programs, tax incentives, and magnet programs. CoOKSON, supra note 9, at 16.

${ }^{321}$ Molly Townes O'Brien, Free at Last: Charter Schools and the "Deregulated" Curriculum, 34 AKRON L. REV. 137, 152-56 (2000)(noting the variety of "tributaries" in the school choice river).

${ }^{322}$ See, e.g., Joseph Viteritti, Choosing Equality: School Choice, the Constitution AND CIVIL SOCIETY (1999)(arguing that school choice may provide more equal opportunity because it would give poor children options that wealthy parents currently have); JOHN E. Coons \& Stephen D. Sugarman, Education by Choice: The Case for Family Control (1978)(articulating the need for choices in the face of values conflicts); JoHN E. CHUBB \& Terry Moe, Politics, Markets AND AmericA's Schools (1990)(arguing that market competition will produce effective school reform). 
among schools for tax support, and attendance by parental selection, rather than by public assignment. Even though charter and voucher schools are prohibited from discriminating in admissions on the basis of religion, by statute and by the federal Constitution, ${ }^{323}$ they permit like-minded people to flock together. They permit parental choice of a school based on the parents' unique set of values and priorities, biases and prejudices.

Some voucher and charter programs permit private and religious schools to participate, and to receive public tax support, based on the number of students attending. The voucher program enacted in Ohio, for example, enables low-income parents to apply for a scholarship to cover the tuition of their school of choice. ${ }^{324}$ The voucher can be used at any of the pre-approved private schools within the borders of the school district, or any of the public schools in adjacent school districts that elected to participate in the program. ${ }^{325}$ Nearly all of the private schools qualified to participate are religious-affiliated schools. None of the adjacent public schools have elected to participate. ${ }^{326}$ This program (and programs like it) has been challenged on the grounds that it violates federal and state constitutional requirements regarding the separation of church and state. ${ }^{327}$ But the constitutionality of these voucher and charter programs has not been adequately addressed under the education clauses of state constitutions.

In Simmons-Harris v. Goff, ${ }^{328}$ the Ohio Supreme Court rejected the claim that the Cleveland pilot voucher program violated the "thorough and efficient" clause of the Ohio Constitution. ${ }^{329}$ In upholding the program, the court focused on funding, saying

${ }^{323}$ See Wendy Parker, The Color of Choice: Race and Charter Schools, 75 TULANE L. REV. 563 (2000)(examining the validity of charter school programs under federal constitutional Equal Protection); Angela Slate Rawls, Eliminating Options Through Choice, 50 EMORY L.J. 363 (2001)(examining the impact of charter and voucher laws on private religious schools that elect to accept publicly-supported tuition money).

${ }^{324}$ See Gatton v. Goff, No. 96CVH-01-193, 1996 WL 466499, at*1 n.1 (Ohio C.P. July 31, 1996) ("The State asserts that the original intention of the General Assembly was to establish a statewide program that would provide this assistance to parents in all school districts, but that it was decided to begin with a pilot program in one district only.").

${ }^{325}$ OHIO REV. CODE $§ \S 3313.976,3313.977$.

${ }^{326}$ Zelman v. Simmons-Harris, 536 U.S. 639, 707 (2002)(Souter, J., dissenting) (observing that " $96.6 \%$ of current voucher money [is] going to religious schools" and that "public schools in adjacent districts hardly have a financial incentive to participate in the Ohio voucher program, and none has").

${ }^{327}$ See Parker, supra note 323, at $566 \mathrm{n} .7$ (detailing challenges to voucher and charter programs in Florida, Cleveland, and Milwaukee based on separation of church and state).

${ }^{328} 86$ Ohio St. 3d 1, 711 N.E.2d 203 (1999).

${ }^{329} I d$. at 11,711 N.E.2d at 212 . The court further held, id. at 4, 711 N.E. $2 d$ at 207 , that the Cleveland Pilot Voucher Program did not violate the Establishment Clause of the First Amendment to the United States Constitution or the Establishment Clause of Section 7, Article I of the Ohio Constitution; did not violate the School Funds Clause of Section 2, Article VI of the Ohio Constitution, or the Uniformity Clause of Section 26, Article II of the Ohio Constitution. It did, however, violate the one-subject rule, Section 15(D), Article II of the Ohio Constitution. Id. at 17, 711 N.E.2d at 216. 
that it could not see how the voucher program "at the current funding level" undermined the state's obligation to public education. ${ }^{330}$ In a footnote, the court went on to add that the program, if greatly expanded, might damage public education and be subject to renewed constitutional challenge. ${ }^{331}$ By focusing on the amount of funds diverted to private schools, the court missed the more important issue relating to the legislature's duty. Under the Ohio Constitution's education clause, the legislature's duty is to secure a single system of common schools.

The constitutional "common school" has specific meaning that must be referenced in the evaluation of school reform programs. Central to that meaning is the requirement that the publicly-supported school system educate children of all classes, religions, and ethnic backgrounds together. In adopting the common school language, the constitutional framers refused to provide tax support for private or sectarian schools. They recognized that competition for public funds by private schools creates disparity in education, segregates communities, and perpetuates strife. Moreover, they were concerned about the dangers of religious and sectarian conflict and violence. For the framers of the Ohio Constitution's education clauses, the only education worthy of public support was a "common" education, not in the sense that it was provided for the common folks, but in the sense that it would bring diverse people together. They chose the common school concept to promote social harmony, create a sense of national identity, and develop affinity. Thus, school reform programs run counter to the constitutional vision when they promote separate schooling for children of discrete ethnic or religious backgrounds. ${ }^{332}$

Moreover, in choosing to mandate the creation of a system of common schools, the constitutional framers rejected the idea of simply subsidizing the existing diverse, parent-initiated and tuition-based schooling arrangements in favor of creating state organization and oversight. They viewed the diversity of the existing arrangements as an impediment to educational progress. The constitutional framers rejected the proliferation of diverse schools in favor of a single system. They also rejected the idea of competition among school districts and a variety of sectarian schools, viewing competition as inefficient, divisive, and ineffective. The rivalry among schools was seen as the greatest impediment to the advancement of education. ${ }^{333}$ Indeed, the problems created by the continuing disparities and competition among local districts generated further constitutional amendments in 1912. These amendments centralized state oversight of the system of public schools by creating a a state superintendent; they further provided for public oversight of the districts through election. ${ }^{334}$ Thus, programs that create competition among schools for

\footnotetext{
${ }^{330} I d$. at 11,711 N.E. $2 \mathrm{~d}$ at 212.

${ }^{331} I d$. at 11 n.2, 711 N.E. $2 \mathrm{~d}$ at 212 n.2.

${ }^{332}$ Although parents have a right to remove their children from the public school and send them to a private religious school, the state has no obligation to fund separate schooling. See Pierce v. Society of Sisters, 268 U.S. 510 (1925) (holding unconstitutional an Oregon law requiring children to attend public schools); see also Meyer v. Nebraska, 262 U.S. 390 (1923) (discussing the liberty interest at stake in teaching).

${ }^{333}$ See supra note 214 and accompanying text.

${ }^{334}$ Oнiо CONST. art. VI, $\S \S 3,4$. See supra notes 299-313 and accompanying text.
} 
public funds or remove schools from state and public oversight also run counter to the constitutional vision and mandate.

The common school ideal was controversial at the time that it was incorporated into the constitution; and it has remained so. It has been referred to as "statist," and assimilationist, and has criticized as originating from impulses that were "conservative, racist and bureaucratic." 335 These critiques of the common school ideal point to serious issues that cannot be easily dismissed. For example, in the name of promoting assimilation, educators have done serious harm to individuals and to minority cultures. ${ }^{336}$ The common school ideal has been criticized for promoting uniformity at the cost of individuality, culture, and conscience. ${ }^{337}$ It has further been argued that the Protestant consensus on values and morality that existed at the time of the common school movement no longer exists, making the concept of a single school that instills community obsolete. ${ }^{338}$ Some school reform advocates view school choice as a promising alternative to an unworkable common school ideal. ${ }^{339}$

Other education theorists, however, suggest that the common school ideal has continuing vitality in a diverse democracy. ${ }^{340}$ Whatever the flaws of that ideal and the institutions established to pursue it, the vision of bringing children together and giving each one an excellent education for participatory citizenship remains a "radical ideal." ${ }^{" 341}$ More importantly, it is also our constitutional ideal.

\footnotetext{
${ }^{335}$ Michael Katz, School Reform Past and Present 3 (1971).

${ }^{336}$ Several educational historians have documented the damage done to Native American children and their communities by programs designed to assimilate Native American children into the mainstream white, Protestant culture. See, e.g., David Wallace AdAms, EduCATION

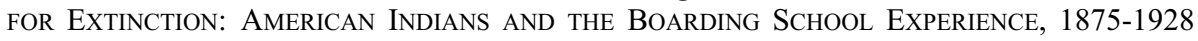
(1995); Joel Spring, Deculturalization and the Struggle for Equality: A Brief History of Education of Dominated Cultures in the United States (2000); Alan Peshrin, Places of Memory: Whiteman's Schools and Native American Communities (1997).

${ }^{337}$ See, e.g., GLENN, supra note 34 , at 10-14, 262-88; RoSEMARy SALOMONE, Visions of Schooling: Conscience, Community and Common Education (2000). But see Sonia Nieto, Affirming Diversity: The Socio-Political Context of Multi-Cultural EDUCATION (3d ed. 2000)(advancing a thesis that multicultural education can be effectively accomplished).

${ }^{338}$ GLENN, supra note 34, at 288.

${ }^{339}$ See, e.g., Witte, supra note 37, at 222 (public schools cannot survive on the "truncated secular theology" of the Enlightenment alone; a "radical new paradigm" for education is being constructed); Rosemary Salomone, Struggling with the Devil: A Case Study of Values in Conflict, 32 GA. L. REV. 633, 695 (1998) (publicly-funded alternatives to the traditional public school could help avoid values-based controversies).

${ }^{340}$ See, e.g., BenJamin Barber, An Aristocracy of Everyone: The Politics of Education and the Future of America (1992); Amy Gutmann, Democratic Education (1987).

${ }^{341}$ Lawrence Cremin, Popular EducAtion And Its Discontents 39 (1989).
} 


\section{CONCLUSION}

The framers of the Ohio Constitution's education provisions intended to use the constitution to transcend - rather than embody - the existing community realities. ${ }^{342}$ In mandating the creation of a common school system, the delegates adopted a contested vision of schooling that rejected the status quo and required change. The concept of a universally available, no-cost, non-sectarian education for children of all classes and colors was and remains controversial. It was incorporated into the constitution only after a sustained effort to sway public opinion. The common school ideal is, in essence, the practical extension of a particular progressive political and educational philosophy of a group of activists who successfully campaigned for its incorporation into the state constitution. Whether one agrees or disagrees with the ideal, the common school ideal was the constitutional winner. Contemporary schooling must be measured against the yardstick of the common school ideal because that is the constitutional mandate.

${ }^{342}$ See Schapiro, supra note 17 , at 394. 